\author{
Laëtitia Demay \\ Sergiy P. Taranenko \\ Anna S. Yanenko \\ Dmytro V. Stupak
}

\title{
UNUSUAL FAUNISTIC COLLECTION FROM THE SCIENTIFIC FUNDS OF THE NATIONAL KYIV-PECHERSK RESERVE
}

Animal bones were discovered in Scientific founds in National Kyiv-Pechersk Reserve. There are 17 pieces. We present here their identification and the description of taphonomic observations. These bones belong to Mammuthus primigenius, Ursus sp. and Cervus sp. They come from various sites from Ukraine. Probably, this collection was formed in the National Kyiv-Pechersk Reserve as a result of the return of materials from Ukrainian museums after the Second World War.

Keywords: National Kyiv-Pechersk Reserve, Illinka Cave, Kyrylivska site, returned collections.

\section{INTRODUCTION}

In 2017, a faunal collection based on mammoth bones was accidentally discovered in the Scientific Funds of the National Kyiv-Pechersk Reserve. Of course, the question of the origin of this collection immediately arose. Upon initial examination of this material, it immediately became clear that the bones came from different locations or sites.

In September 2017, the collection was analyzed by Laëtitia Demay (table 1).

Table 1. Inventary. / Табл. 1. Склад фауністичної збірки.

\begin{tabular}{|l|l|l|l|l|l|l|}
\hline $\mathbf{N}^{\circ}$ & Notes & $\mathbf{N}^{\circ}$ bis & TAXON & ELEMENT & Lat. \\
\hline 1 and 2 & & & Mammuthus & tusk & $/$ \\
\hline 3 and 12 & & & Mammuthus & humerus & dext \\
\hline 4 & & & Mammuthus & humerus & dext \\
\hline 5 & & & Mammuthus & mandible & sin \\
\hline 6 & & 3139 & Mammuthus & ulna & dext \\
\hline 7 & & & Ursus sp. & femur & dext \\
\hline 8 & & & Mammuthus & humerus & sin \\
\hline 9 & & & Cervidae (Cervus sp.) & skull and antler & sin \\
\hline 10 & Ilinka & 73 & Ursus sp. & humerus & dext \\
\hline 11 & & & C. elaphus & antler & sin \\
\hline 13 & & 3169 & Mammuthus & ulna & dext \\
\hline 14 & & & C. elaphus & skull and antler. slaughter antler ; median antler ; part of palms & dext \\
\hline 15 & & & Ursus sp. & mandible + root fragments of 3 molars & sin \\
\hline 16 & & & Mammuthus & upper molar & sin \\
\hline 17 & & & Mammuthus & upper molar & \\
\hline
\end{tabular}

Demay Laëtitia, PhD, Research Fellow, Muséum national d'Histoire naturelle, rue René Panhard, 1, Paris, 75013, France;

ORCID: 0000-0003-4930-7030, e-mail: laetitia.demay@ mnhn.fr

Taranenko Sergiy, PhD, Head of the Scientific and Research Sector of Archaeology National Preserve «Kyiv-Pechersk lavra» , 9 Lavrska, Str., 01015 , Kyiv, Ukraine; ORCID: 0000-0003-0590-9726, e-mail: taransun@ukr.net

Yanenko Anna, PhD, Research Fellow of History and Archaeology Research Department, National Preserve "Kyiv-Pechersk Lavra", 9 Lavrska, Str., Kyiv, 01015, Ukraine; ORCID: 0000-0003-0713-3087, e-mail: pudovkina@ukr.net

Stupak Dmytro, PhD, Research Fellow, the Institute of Archaeology, the National Academy of Sciences of Ukraine, Heroiv Stalinhrada ave., 12 , Kyiv, 04210, Ukraine; ORCID: 0000-0002-0809-2179, e-mail: stupak17@ukr.net 


\section{METHODS}

We processed to the paleontological identification (species and anatomical elements) and taphonomical analyses (Efremov 1940; Behrensmeyer 1978; Denys, Patou-Mathis 2014).

The measurements of bones were made according to the methods applied on mammals and particularly Elephantids developed by Von den Driesch (1976), Agenbroad (1994) and Averianov (1996). The material used is a flexible tape measure, a rigid tape measure and a $150 \mathrm{~mm}$ caliper.
Concerning Ursus sp., we used Weinstock (2009) for determination of ages and Petronio, di Canzio and di Stefano (2003) to distinct species by morphometry.

Concerning mammoth, age classes were estimated from the growth stages of long bones (Laws 1966; Krumrey, Buss 1968; Hanks 1972; Haynes 1991; Lister 1999) and teeth (Osborn 1942; Vaufrey 1955; Coppens 1965; Shoshaniand, Tassy 1996).

To identify if these bones belong to M. primigenius, and determine the sex, we used data obtained about other known specimens (table 2).

Table 2. Specimens of Mammuthus primigenius used for osteometric comparisons.

Табл. 2. Зразки Mammuthus primigenius, що використовуються для остеометричних порівнянь.

\begin{tabular}{|c|c|c|c|c|c|c|c|}
\hline Individual & $\begin{array}{l}\text { Year of } \\
\text { discovery }\end{array}$ & Locality & Age & Sex & $\begin{array}{l}\text { Heightat } \\
\text { the withers } \\
\text { (in cm) }\end{array}$ & $\begin{array}{c}\text { Chronology and } \\
\text { dates }\end{array}$ & References \\
\hline Rottweil & 1967 & $\begin{array}{c}\text { Germany, } \\
\text { Bade- } \\
\text { Wurtemberg }\end{array}$ & $>25$ у.о. & $\mathrm{F}$ & 250 & $\begin{array}{l}\text { End of Upper } \\
\text { Pleistocene }\end{array}$ & Ziegler, 2001 \\
\hline Kastykhtakh & 2008 & $\begin{array}{l}\text { Russia, } \\
\text { Taymir }\end{array}$ & 38-45 у.о. & $\mathrm{F}$ & 224 & 32 070-30 565 BP & Kirillova et al., 2012 \\
\hline Oyesh river & $\begin{array}{l}1988- \\
1991\end{array}$ & $\begin{array}{l}\text { Russia, } \\
\text { Siberia }\end{array}$ & adults.l. & $\mathrm{F}$ & $215(240)$ & 14000 BP & Averianov, 1994 \\
\hline Sanga-Yuryakh & 1908 & $\begin{array}{l}\text { Russia, } \\
\text { Yakoutia }\end{array}$ & 54-60 у.о. & $\mathrm{F}$ & l & $39000-37000 \mathrm{BP}$ & $\begin{array}{l}\text { Vollosovich, } 1909 \\
\text { Garrut, } 1964\end{array}$ \\
\hline $\begin{array}{l}\text { Aa } \\
=\text { Arques }\end{array}$ & 1908 & $\begin{array}{c}\text { France, } \\
\text { Pas-de-Calais }\end{array}$ & $40-50$ у.о. & $\begin{array}{c}\mathrm{F} \\
\text { but size } \\
\text { of } \mathrm{M}\end{array}$ & 301 & $\begin{array}{l}\text { Middle-Upper } \\
\text { Pleistocene }\end{array}$ & Pontier, 1913 \\
\hline Ahlen & 1910 & $\begin{array}{l}\text { Germany, } \\
\text { North Rhine- } \\
\text { Westphalia }\end{array}$ & 31-34 у.о. & M & 320 & $41000 \mathrm{BP}$ & Siegfried, 1959 \\
\hline Borna & $\begin{array}{l}1908- \\
1909\end{array}$ & $\begin{array}{l}\text { Germany, } \\
\text { Saxony }\end{array}$ & $25-30$ у.о. & M & 320 & Upper Pleistocene & Felix, 1912 \\
\hline Polch & 1936 & $\begin{array}{l}\text { Germany, } \\
\text { Rhineland- } \\
\text { Palatinate }\end{array}$ & $60-70$ у.о. & M & 320 & Upper Pleistocene & Koenigswald, 1989 \\
\hline Pfännerhall & 1953 & $\begin{array}{c}\text { Germany, } \\
\text { Saxony-Anhalt }\end{array}$ & $\sim 60$ у.о. & M & 300 & Saalian & Toepfer, 1957 \\
\hline Siegsdorf & 1975 & $\begin{array}{c}\text { Germany, } \\
\text { Upper Bavaria }\end{array}$ & $49->52$ y.o. & M & 360 & $47000 \mathrm{BP}$ & Ziegler, 1994 \\
\hline Condover & 1986 & $\begin{array}{l}\text { Great Britain, } \\
\text { Shropshire }\end{array}$ & 28 y.o. & M & l & $14000 \mathrm{BP}$ & Lister, 2009 \\
\hline $\begin{array}{l}\text { Lena } \\
\text { (= Adams) }\end{array}$ & 1799 & $\begin{array}{l}\text { Russia, } \\
\text { Siberia }\end{array}$ & 43-50 y.o. & M & 320 & $34450 \pm 2500 \mathrm{BP}$ & $\begin{array}{l}\text { Adams, } 1808 \\
\text { Pfitzenmayer, } 1907\end{array}$ \\
\hline Berezovka & 1900 & $\begin{array}{l}\text { Russia, } \\
\text { Siberia }\end{array}$ & 30-35 у.о. & M & 265 & $\begin{array}{l}\text { End of Upper } \\
\text { Pleistocene }\end{array}$ & Pfizenmayer, 1926 \\
\hline $\begin{array}{l}\text { Lyakhov } \\
\text { (= Atrikanova } \\
\text { ouVollossovitch) }\end{array}$ & 1914 & $\begin{array}{l}\text { Russia, } \\
\text { Lyakhov islands }\end{array}$ & 30 у.о. & M & l & $49000 \mathrm{BP}$ & $\begin{array}{l}\text { Coppens, } 1958 \\
\text { Vollossovich, } 1914 \\
\text { Viola, } 2014\end{array}$ \\
\hline Taimyr & 1948 & Russia, Taimyr & 50-55 y.o. & M & 265 & $11450 \pm 250 \mathrm{BP}$ & Garrut et Dubinin, 1951 \\
\hline Sevsk & $\begin{array}{l}1988- \\
1991\end{array}$ & Russia, Siberia & adults.l. & M & 235 & $\sim 14000$ & $\begin{array}{l}\text { Vereshagin, Tikhonov, } 1986 \\
\text { Maschenko et al., } 2006\end{array}$ \\
\hline
\end{tabular}




\section{DESCRIPTION AND RESULTS}

$\mathrm{n}^{\circ} 1$ and $\mathrm{n}^{\circ} 2$

It is a tusk (fig. 1), that we can not lateralized for sure.

This tusk seems to belong to Mammuthus primi- genius. Moreover, according to the measurements this tusk belongs to a male (fig. 2).

This tusk is relatively well preserved. The surface is covered by manganese and ferric deposits relied to post-depositional water percolation.

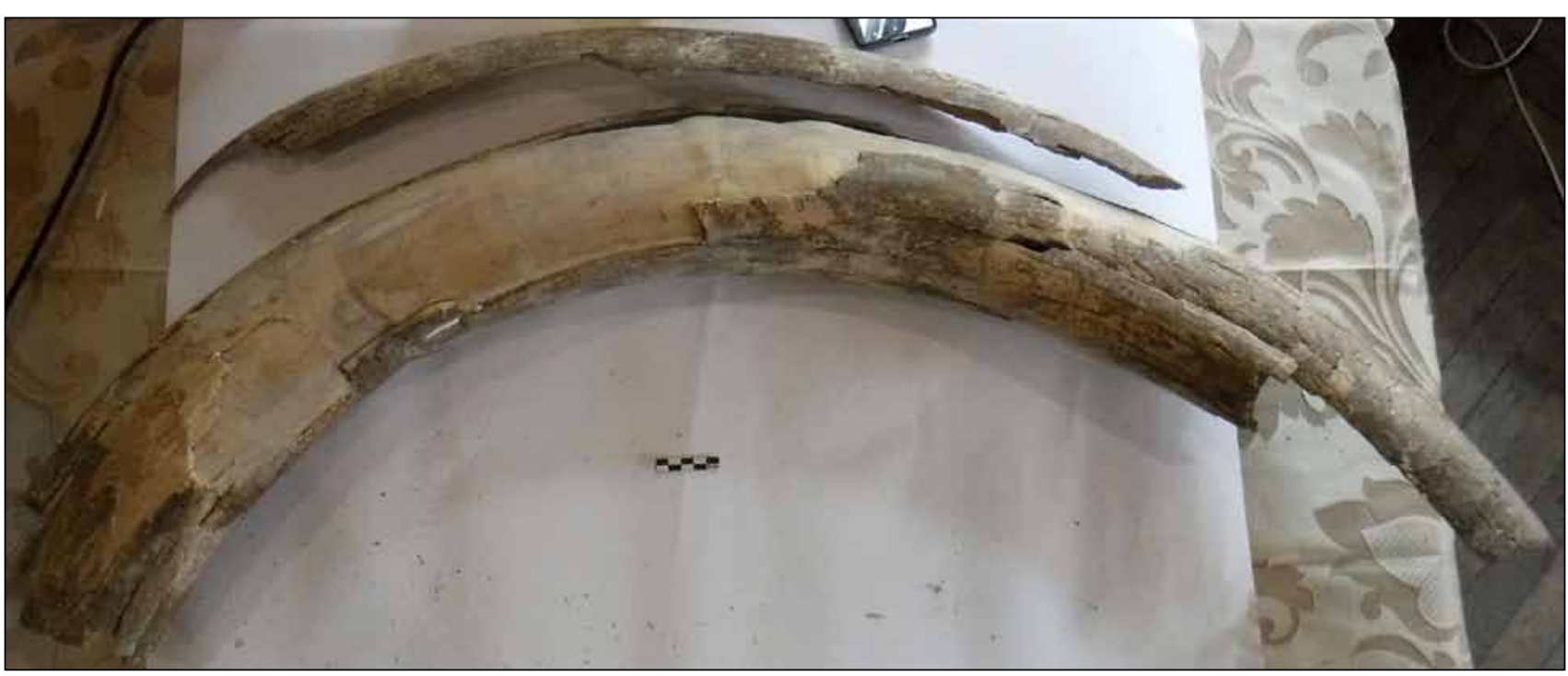

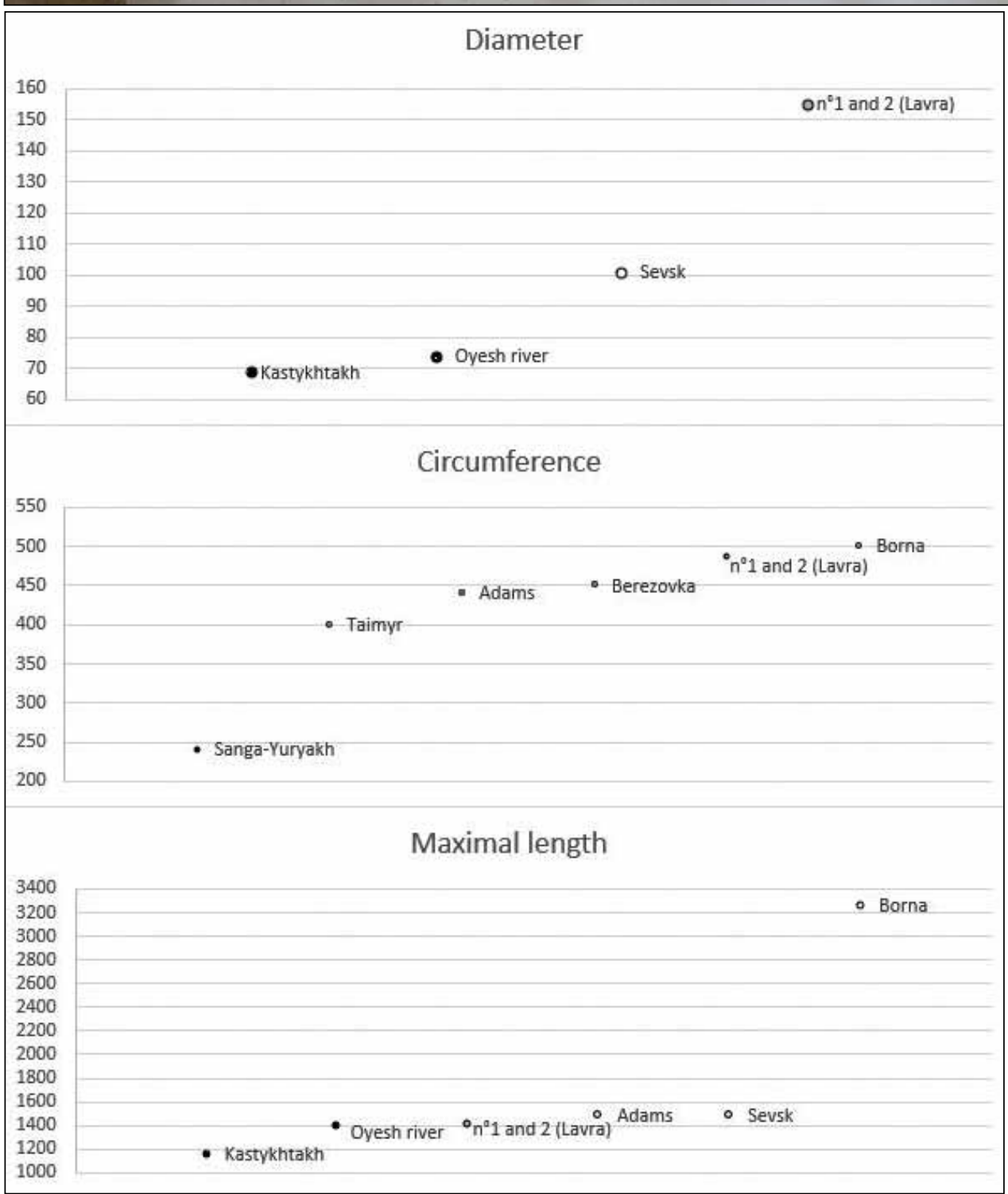

$\boldsymbol{A}$

Fig. 1. Tusk of mammoth. Рис. 1. Бивень мамонта.
Fig. 2. Measurements of M. primigenius tusks.

Рис. 2. Морфологічні показ ники бивнів М. primigenius. female $\because$ male $\because \because$ 


\section{$\mathrm{n}^{\circ} 3$ and $\mathrm{n}^{\circ} 12$}

It is a distal end and a diaphysis of a right humerus (fig. 3).

According to measurements (fig. 4) this humerus could belong to a female. The distal end is fused, so this individual was more that stage XVla (> 18-26 years old).

The coloration is white. The surface is exfoliated and presents plant root marks. So these bone could stay in open air, then buried in subsurface.

\section{$\mathrm{n}^{\circ} 4$}

It is a diaphysis of a right humerus (fig. 5).

Extremities are not fused, so this individual is a young adult less than stage XVla $(<18-26$ years old). Moreover, this humerus is characterized by a pathology.

The surface is covered by manganese deposits and plant root marks.

Fig. 4. Osteometry of humerus of mammoths.

Рис. 4. Остеометрія плечової кістки мамонтів.
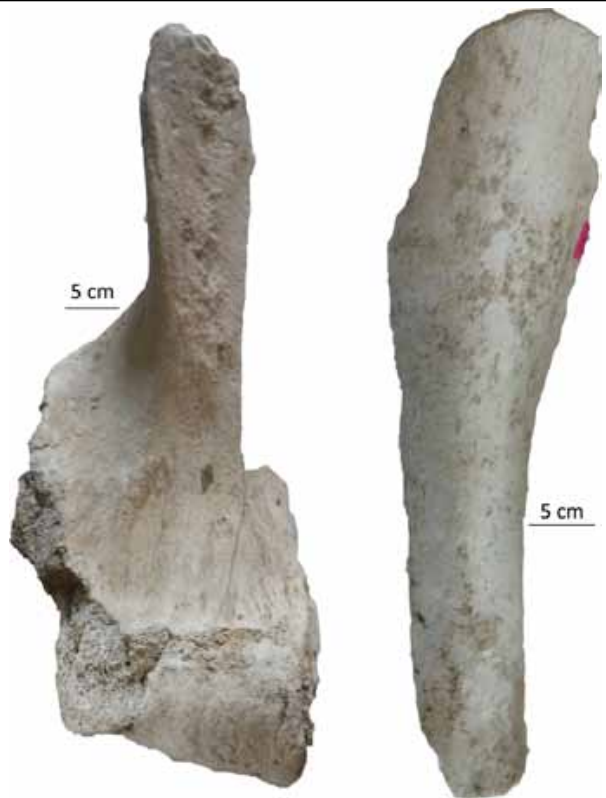

Fig. 3. Right humerus of mammoth in anterior view.

Рис. 3. Права плечова кістка мамонта. Вигляд спереду.

V

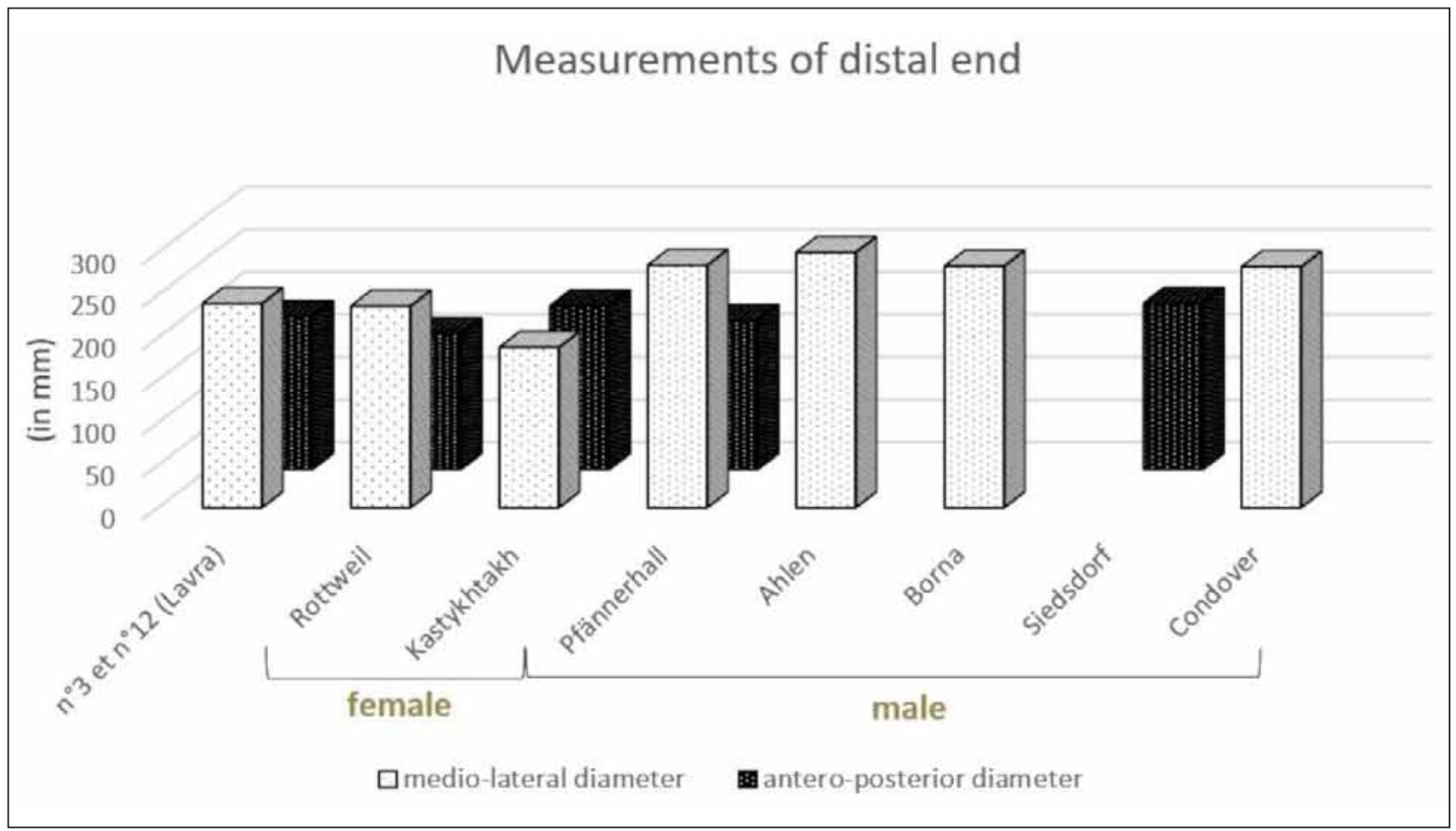

\section{$n^{\circ} 5$}

It is a fragment of mandible of mammoth (fig. 6).

This mandible could belong to a male (fig. 7).

The surface is covered by manganese deposits and plant root marks.

\section{$n^{\circ} 6$}

It is a left ulna of mammoth (fig. 8).

The bone is too damaged for reliable measurements. The distal end is fused so this individual is an adult more than stage XVIIla-XX ( $>$ 25-35 years old) if it is a female and more than stage XXII-XXX (> 36 years old) if it is a male.

The surface is very damaged, with exfoliation, removal of cortical bone and fissurations due to weathering. So this bone stayed in open air and then was recovered by sediments containing manganese deposits.

The proximal part of diaphysis was burned.

An indistinct inscription is visible on the surface, probably in pencil — “№3139". 


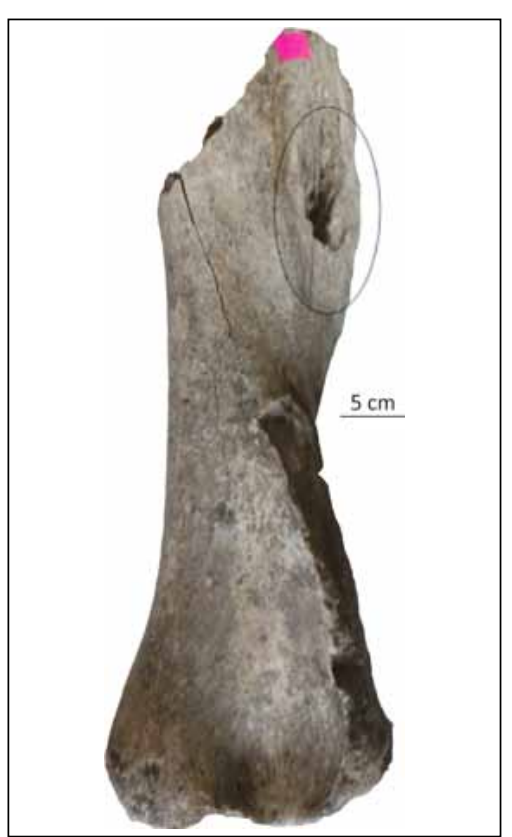

Fig. 7. Internal widths of the mandibular symphysis of mammoths.

Рис. 7. Внутрішня ширина між симфізами нижньої щелепи мамонтів.

Fig. 5. Right humerus of mammoth in lateral view.

Рис. 5. Права плечова кістка мамонта. Вигляд збоку.

Fig. 6. Mandible of mammoth in occlusal view.

Рис. 6. Нижня щелепа мамонта. Вигляд з внутрішньої сторони. $\nabla$
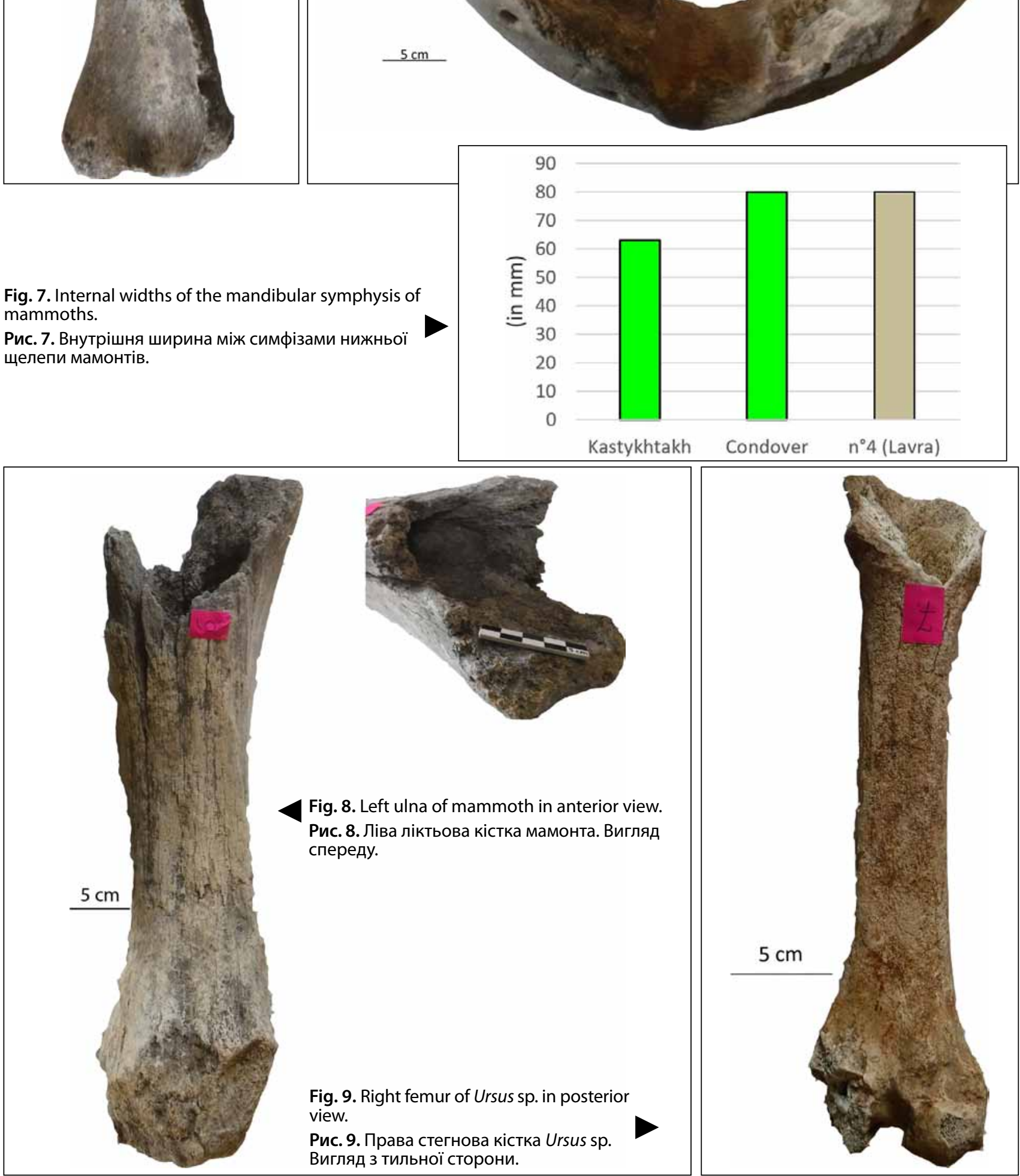


\section{$\mathrm{n}^{\circ} 7$}

It is a right femur of an adult bear (fig. 9).

The distal end is fused so this individual is an adult more than 6 years old. The surface presents plant root marks, also as marks due to charriage-à$\mathrm{sec}$ and/or trampling and manganese and ferric deposits. So this bone was altered by soil movements. Moreover, a red chemical product was applied to consolidate this bone and several recent tool marks were observed.

\section{$\mathrm{n}^{\circ} 8$}

It is a right humerus of mammoth (fig. 10).

The proximal part is fused so this individual is an adult more than stage XVla ( $>18-26$ years old) if it is a female and more than stage XVIIla-XX (> 25-35 years old) if it is a male.

The surface is covered by manganese deposits and plant root marks. Moreover, the proximal part is covered by red color deposits.

\section{$\mathrm{n}^{\circ} \mathbf{9}$}

It is a part of a right antler with a fragment of skull of Cervidae (Cervus sp.) (fig. 11).

The surface is a little bit exfoliated and presents a little bit of manganese and ferric deposits.

\section{$\mathrm{n}^{\circ} 10$}

It is a left humerus of an adult bear (fig. 12). The note "c. Илинка" and "№73" is mentioned on this bone.
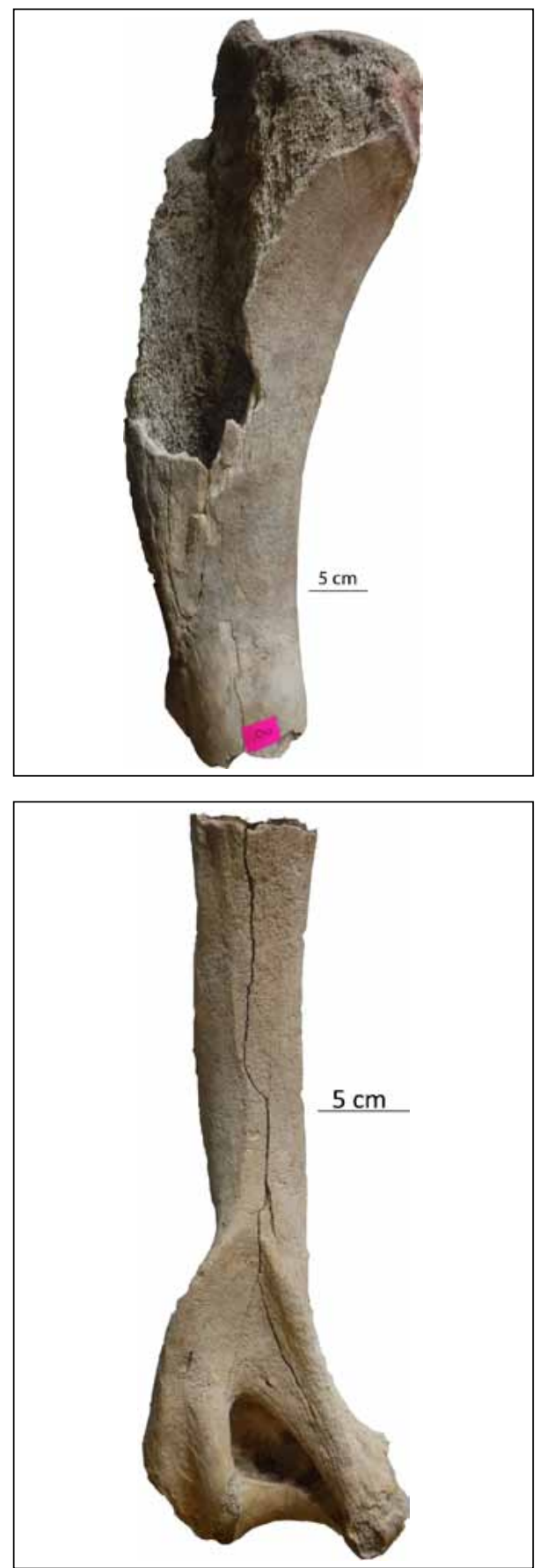

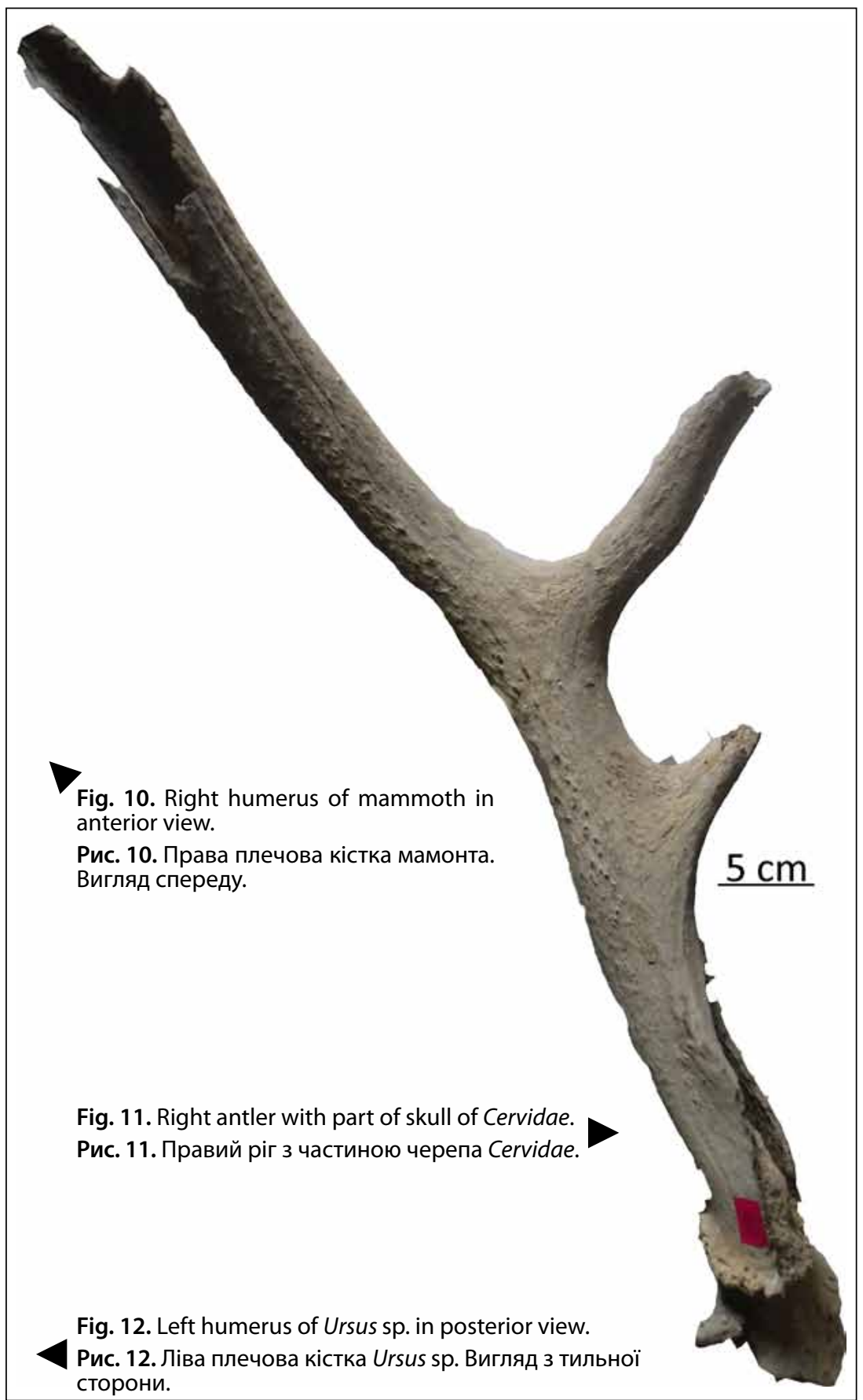
сторони. 
The distal end is fused so this individual is an adult more than 4 years old. Concerning the distal end, the medio-lateral diameter is $110 \mathrm{~mm}$. So it is situated in the confusion zone between $U$. spelaeus and U. arctos (fig. 13).

According to the morphology it looks more like U. spelaeus (fig. 14).

The surface presents plant root marks, also as marks due to charriage-à-sec and/or trampling and manganese and ferric deposits. So this bone was altered by soil movements.

Moreover, a red chemical product was applied to consolidate this bone.

\section{$\mathrm{n}^{\circ} 11$}

It is a fragment of a right antler of Cervus $s p$. (fig. 15).

The surface is a little bit exfoliated and presents a little bit of manganese and ferric deposits. There are many marks of modern tools.

\section{$\mathrm{n}^{\circ} 13$}

It is a left ulna of mammoth (fig. 16).

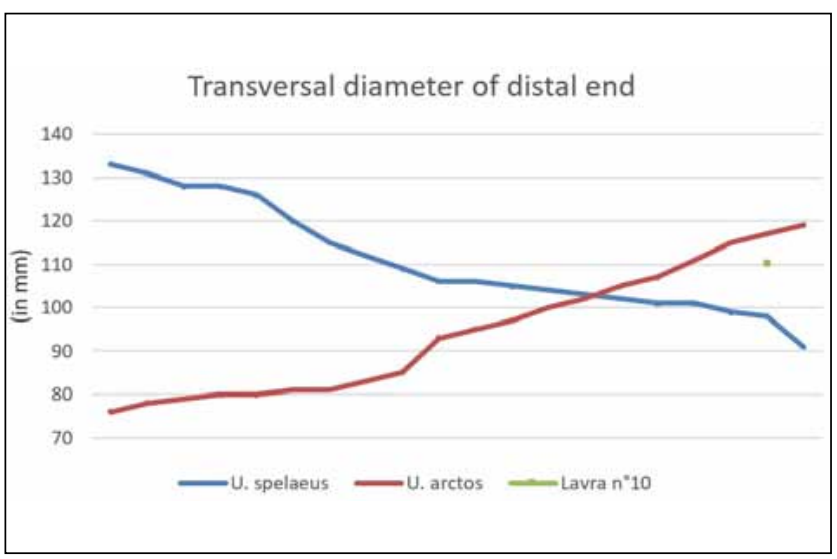

Fig. 13. Measurements of the distal end of humerus between $U$. spelaeus and U. arctos, compared with bone of bear $\mathrm{n}^{\circ} 10$.

Рис. 13. Метричні показники дистального кінця плечової кістки U. spelaeus та U. arctos, порівняно з кісткою ведмедя №10.
According to the dimensions of this ulna, it could belong to a female (fig. 17). Whether it is a male or a female, this individual was an adult more than stage XVIIIa-XX (> 25-35 years old).

The surface is exfoliated and presents marks due to charriage-à-sec and/or trampling. So this bone was altered by soil movements. Moreover, the proximal part is covered by red color deposits.

On the bone there is a postage stamp with an ink number - "3169" (fig. 16b). At the end of the $19^{\text {th }}$ beginning of the $20^{\text {th }}$ century, during the documentation process of museum collections, it was a common practice to stick a stamp with an inventory number according to the inventory book on a collectible item. According to the inventory book (catalog) of the Archaeological Museum of Kyiv University, which is preserved in the fund "Museum of Antiquities of the University of St. Vladimir" (NA IA NAS of Ukraine, f. 13, d. 94) numbers "3103-3187" were given to "bone objects found in pit-dwelling on Kirillovskaya street, No. 61" (on Russian) (sheets 49 verso - 50). It is reasonable to assume that bone No. 13 comes from the collection of the Kyrylivska Paleolithic site.

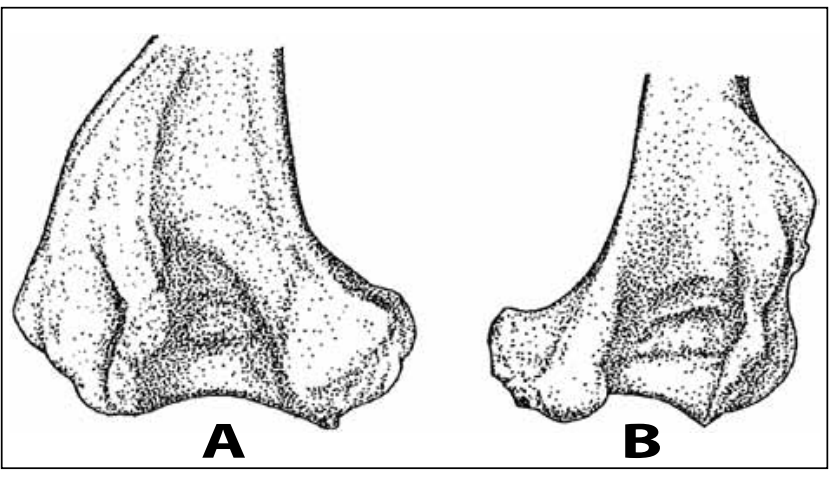

Fig. 14. Distal end of humerus in posterior view (Petronio, di Canzio and di Stefano 2003). A : U. spelaeus; B : U. arctos.

Рис. 14. Дистальний кінець плечової кістки. Вигляд з тильної сторони (Petronio, di Canzio and di Stefano 2003). A : U. spelaeus; B : U. arctos.
Fig. 15. Fragment of right antler of Cervus sp.

Рис. 15. Фрагмент правого рогу Cervus sp.

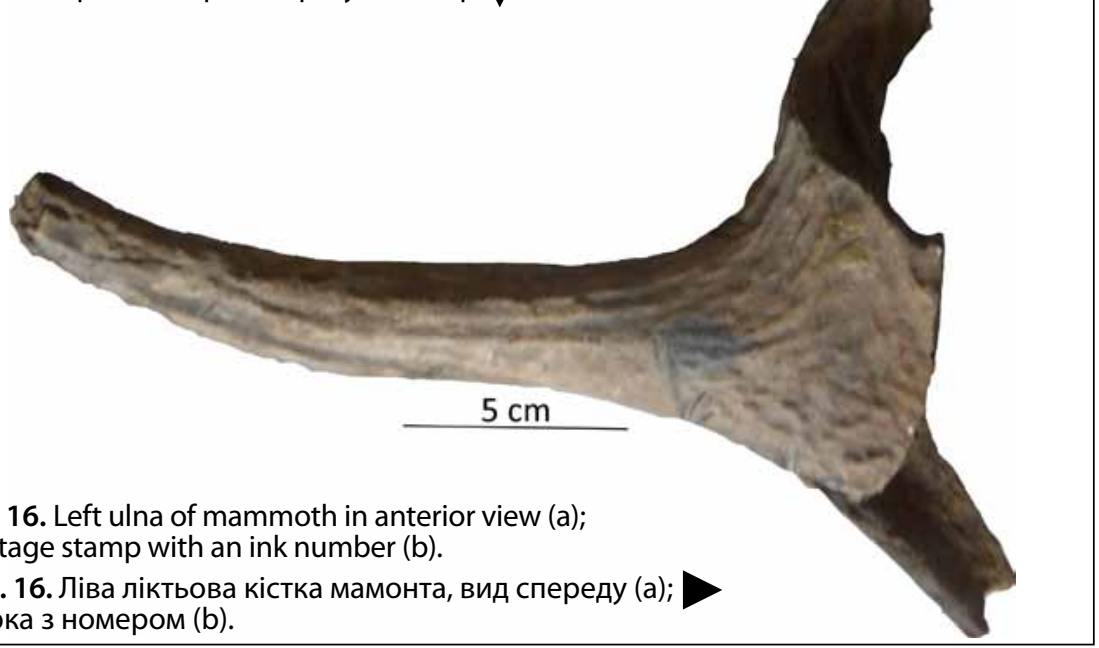

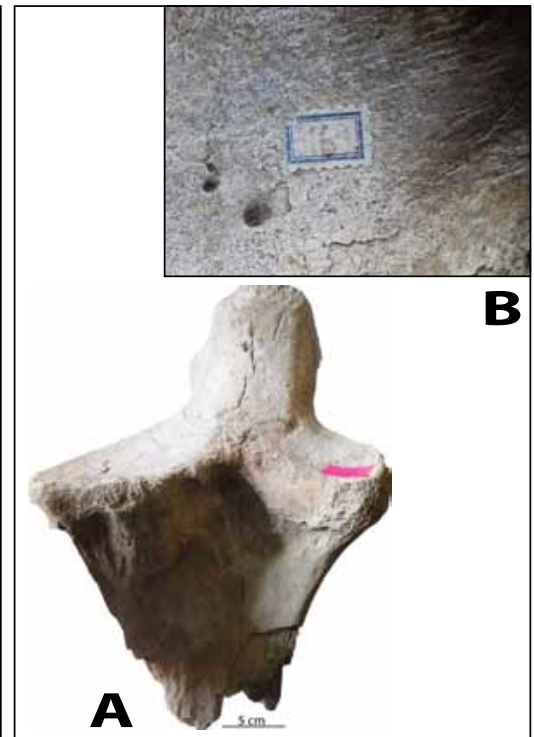




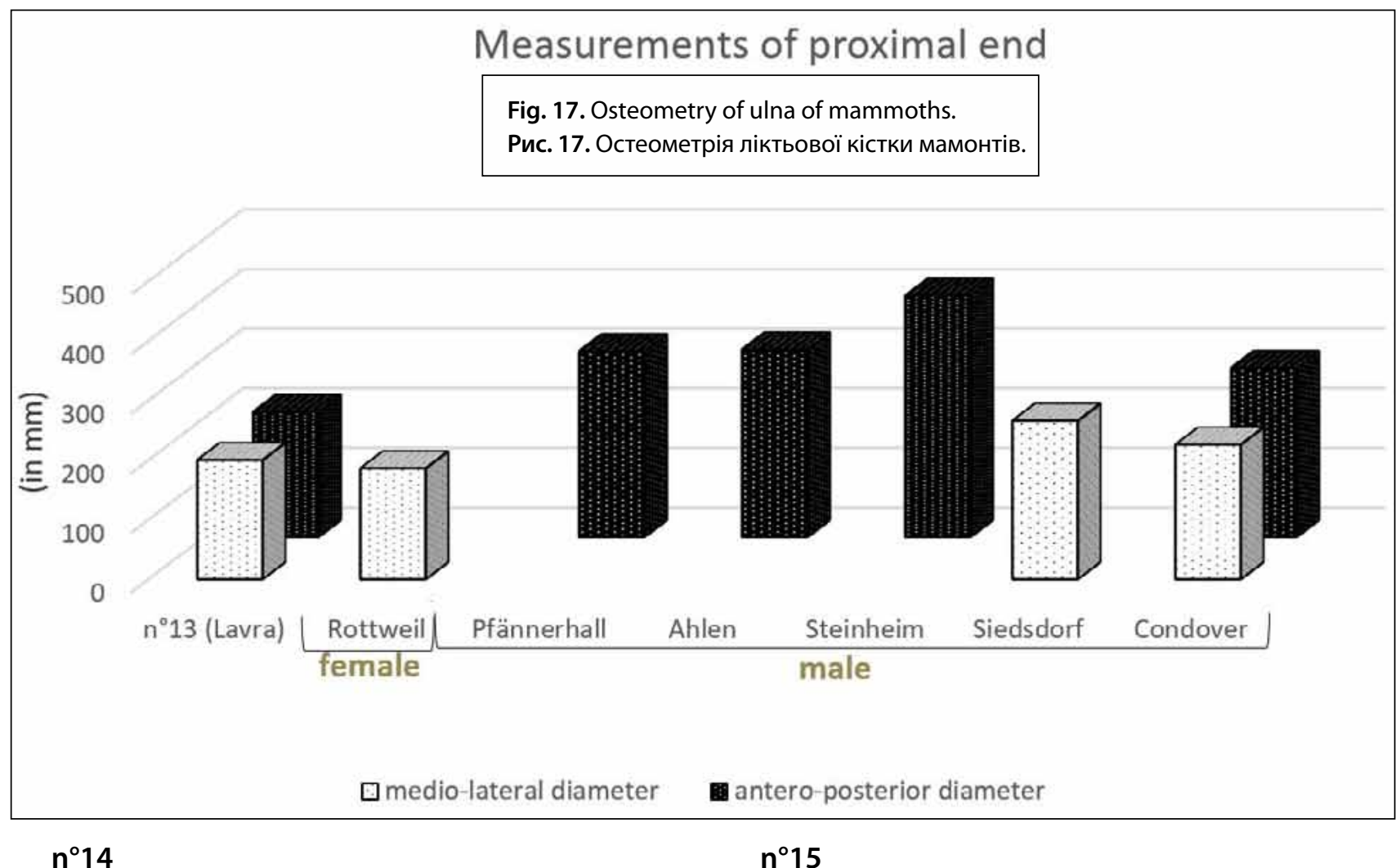

It is a right antler with a fragment of skull of an adult Cervus elaphus (fig. 18).

The surface is exfoliated and presents deposits of manganese.

It is a right hemi-mandible of bear with roots of three molars (fig. 19).

The surface is exfoliated due to weathering and presents plant root marks.

Fig. 18. Right antler with part of skull of Cervus elaphus in lateral view.

Рис. 18. Правий ріг з частиною черепа Cervus elaphus. Вигляд збоку.

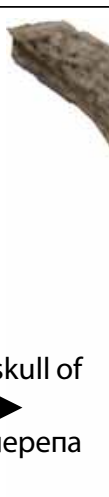

Fig. 19. Right hemi-mandible of Ursus sp. in lingual view.

Рис. 19. Права половина нижньої щелепи Ursus sp. Лінгвальна сторона.
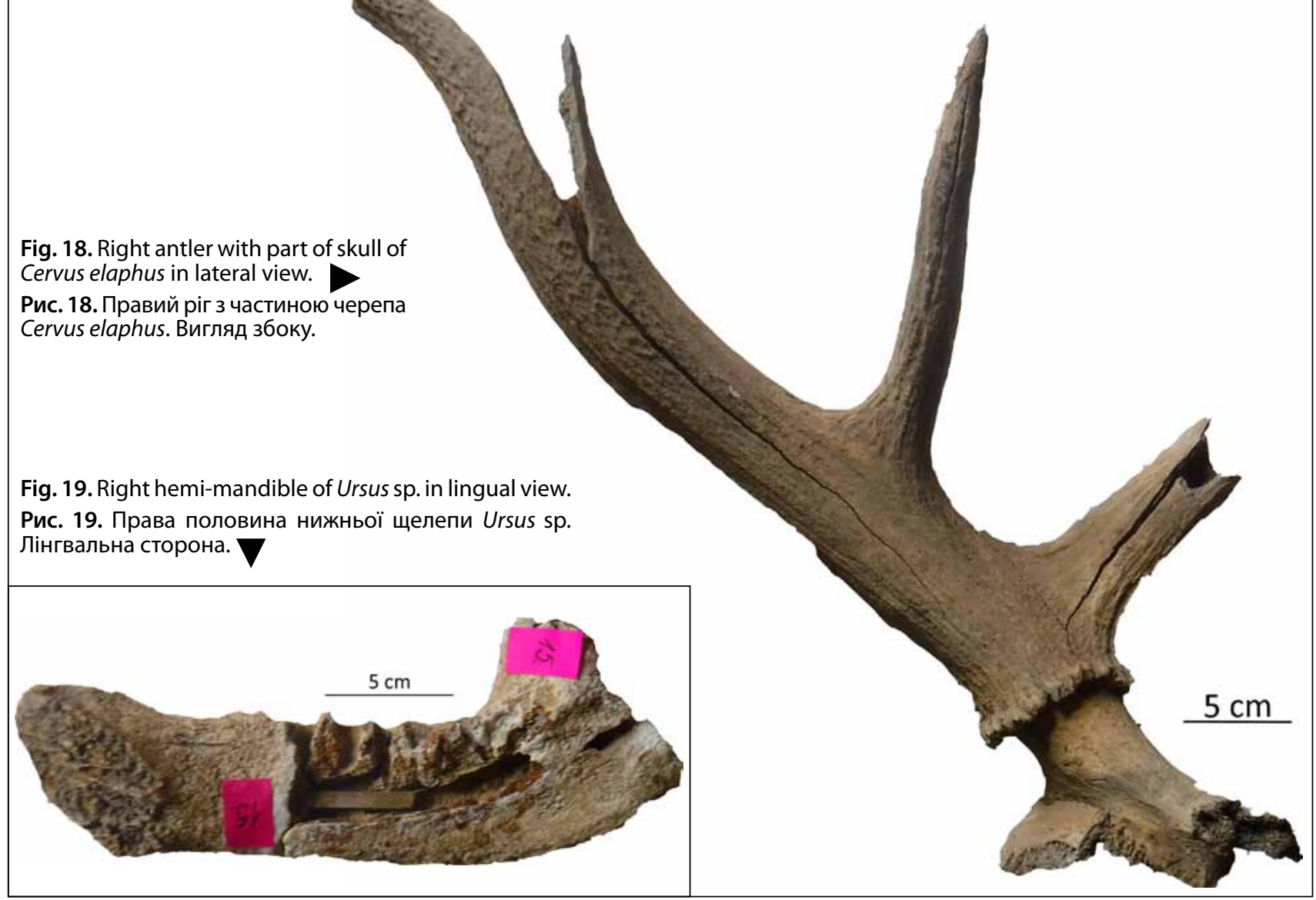


\section{$n^{\circ} 16$}

It is a left upper molar (fig. 20).

According to the laminar frequency and the width of enamel it is a Mammuthus primigenius. According to the dimensions and the number of plates it is a $\mathrm{M}^{3}$ wich belongs to a matured adult (stages XXI-XXII - 35-45 years old) (table 3).

\section{$n^{\circ} 17$}

It is a left upper molar (fig. 21).

According to the laminar frequency and the width of enamel it is a Mammuthus primigenius. According to the dimensions and the number of plates it is a $\mathrm{M}^{2}$ or a $\mathrm{M}^{3}$ wich belongs to an adult (table 3).

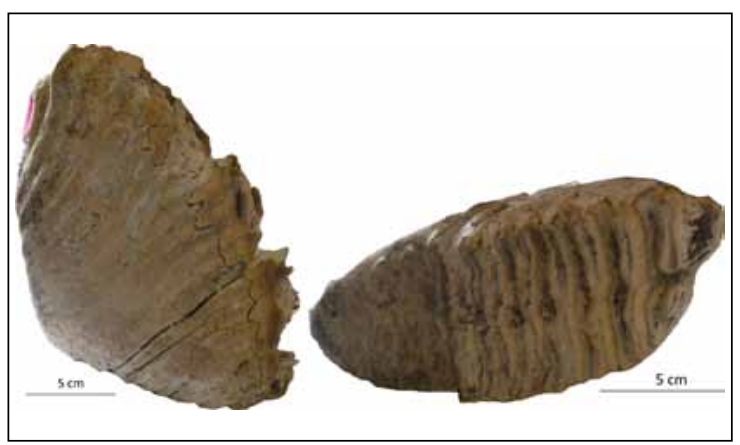

Fig. 20. Left upper molar of Mammuthus primigenius. Рис. 20. Лівий верхній моляр Mammuthus primigenius.

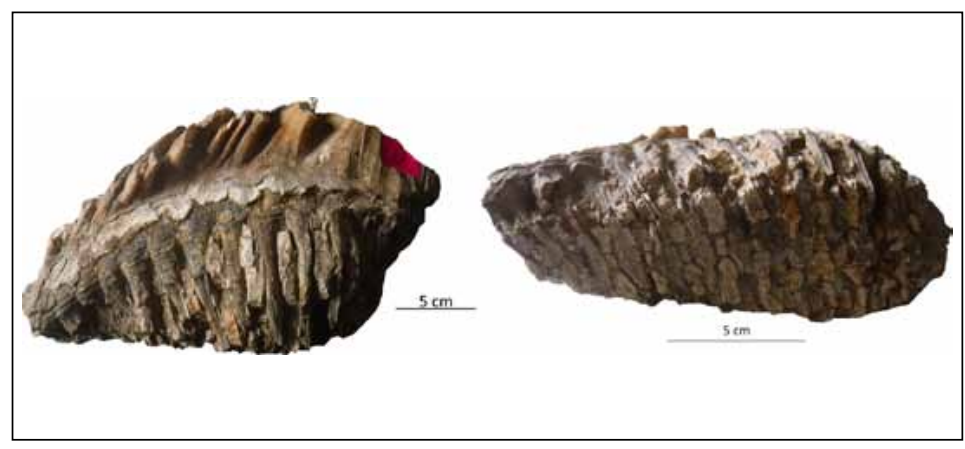

Fig. 21. Left upper molar of Mammuthus primigenius.

Рис. 21. Лівий верхній моляр Mammuthus primigenius.

Table 3. Data about molars of mammoth.

Табл. 3. Характеристики молярів мамонта.

\begin{tabular}{|c|c|c|c|c|c|c|c|c|}
\hline $\mathbf{N}^{\circ}$ & Lat. & $\begin{array}{c}\text { Number } \\
\text { of plates }\end{array}$ & $\begin{array}{c}\text { Eruption and } \\
\text { wear stages }\end{array}$ & $\begin{array}{c}\text { Laminar } \\
\text { frequency }\end{array}$ & $\begin{array}{c}\text { Width of enamel } \\
\text { (in } \mathbf{~ m m} \text { ) }\end{array}$ & $\begin{array}{c}\text { Mesio-distal } \\
\text { diameter occ. } \\
\text { (in } \mathbf{~ m m} \text { ) }\end{array}$ & $\begin{array}{c}\text { Vestibulo-lingual } \\
\text { diameter occ. } \\
\text { (in } \mathbf{~ m m} \text { ) }\end{array}$ & $\begin{array}{c}\text { Mesio-distal } \\
\text { diameter } \\
\text { tot. (in } \mathbf{~ m m} \text { ) }\end{array}$ \\
\hline 16 & $\mathrm{G}$ & 19 & $\mathrm{x}, 8 \mathrm{E}, 4 \mathrm{D}, 7 \mathrm{C}^{*}$ & 8 & 1,8 & 171 & 88 & 260 \\
\hline 17 & $\mathrm{G}$ & 14 & $/$ & 8 & 1 & 173 & 76 & 232 \\
\hline
\end{tabular}

" (E : used; D : few used; C : erupting).

* (E : спрацьований; D : ледь спрацьований; C : той, що прорізується).

\section{SYNTHESIS}

This assemblage is composed of at least six individuals:

- 1 bear (adult s.l.)

- 2 Cervus sp. (male adult s.l.)

- 3 mammoths (1 female adult s.l. ; 1 male adult s.l., 1 young adult)

According to the taphonomic observations, it seems to have at least three different assemblages.

\section{DISCUSSION}

We are certain of the presence of elements from Illinka (fig. 22).

Concerning some other bones, they could come from Kyrylivska site (fig. 22), according to the taphonomic observations on bones which are similar with those of the material preserved in the National Museum of History of Ukraine and archival research.

Odesa region is characterized by the presence of natural karst cavities. In 1938 T. Grytsai discovered and excavated the Illinka Cave (Підоплічко 1949) (fig. 23). A large number of animal bones and flint fragments were found (Рощін 1939; 1941). T. Grytsai and O. Dobrovolskyi (1950) led excavations between 1939 and 1945. Stone material is not abundant and is represented by processed flints and quartzite. The collection is subdivided into three complexes of different times, among which the earliest is the most numerous. Most often, researchers considered it most likely that it belongs to the Middle Paleolithic, but there were other assumptions (Замятнін 1950; Ефименко 1953; 1954; Сапожников, Сапожникова 1989). The geological position of this site was described by K.K. Pronin (1999). Besides stone tools some bone polishers and drilled bear canines were found. One of the bone tools was 14C dated to $27.500 \pm 210$ BP (Ki-11681) (Сапожніков 2005). Another date was furnished about bear bone to $41.700 \pm 1200$ (VERA-2195) (Kavcik-Graumann et al. 2016). This cave was probably alternated between humans and bears. The fauna of Illinka cave (MNI: 468; NR: 29971) (Підоплічко 1956; Ridush, 2009) includes mainly cave bear remains (MNI: 374; NR: 29336), then cave hyaena, wolf, red fox, corsac fox, badger, cave 
lion, naked mole-rat, european hamster, porcupine, hare, pika, horse, woolly rhinoceros, bison, saiga antelope, roe deer and red deer (fig. 24).

In the beginning of 2000, a cooperation between the university of Vienna and the Museum of Odesa permitted to study cave bear remains (Kavcik-Graumann et al. 2016). The authors conclude that the cave bears of the Illinka cave belong to Ursus ingressus. It was a massive herbivorous (Bocherens et al. 2011) cave bear larger than U. spelaeus which weight was estimated around $350 \mathrm{~kg}$ to $600 \mathrm{~kg}$; it lived in Central and Eastern Europe within continental environments with cold and arid climate (Rabeder et al. 2004). Some researchers still question them to be different species, but rather subspecies (Baca et al. 2012).

Fig. 22. Localisation of the potential origins of the bones from know assemblages, in Ukraine.

1: Odessa region (Illinka); 2: Kyiv (Kyrylivska).

Рис. 22. Вірогідні місця походження кісток із відомих збірок в Україні.

1: Одеська область (Іллінка); 2: Київ (Кирилівська).

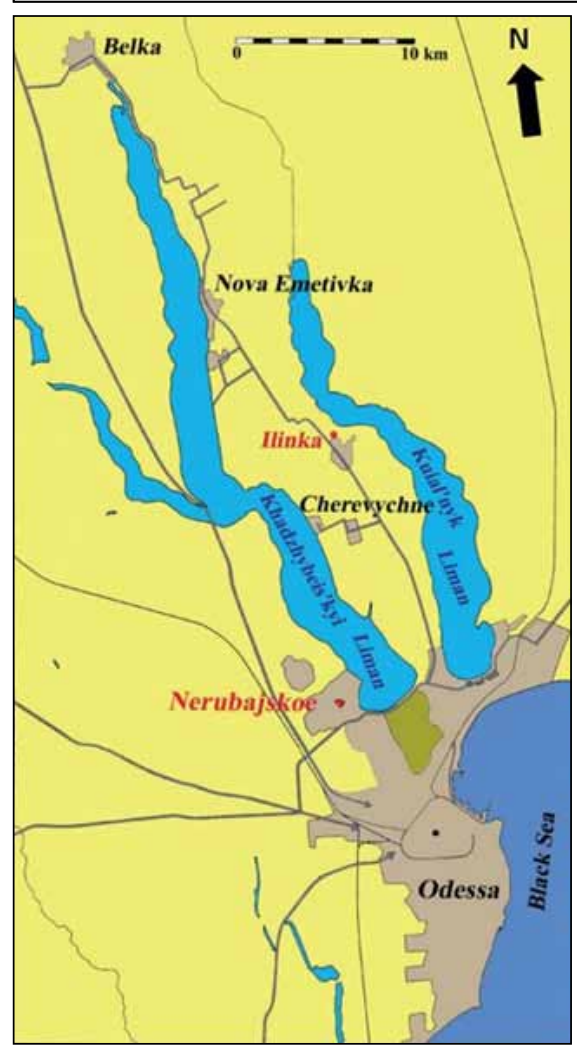

Fig. 23. Geographic position of the site of Illinka (Ukraine) (Kavcik-Graumann et al. 2016 after Nagel et al. 2005).

Рис. 23. Географічне розташування стоянки Іллінка (Україна) (Kavcik-Graumann et al. 2016 za Nagel et al. 2005).

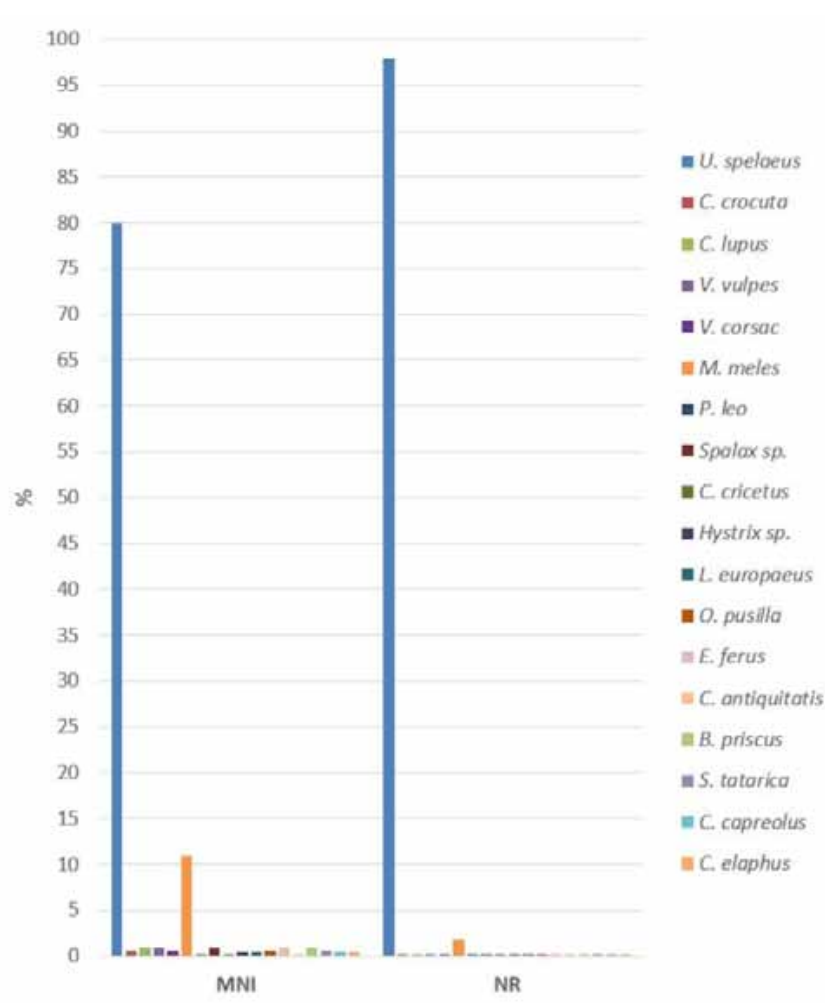

Fig. 24. Faunal spectrum of Illinka (Ukraine) in percentage (after data from Підоплічко 1956; Ridush 2009).

Рис. 24. Фауністичний спектр Іллінки (Україна) у відсотках (за даними Підоплічко 1956; Ridush 2009). 
Concerning the site of Kyrylivska, it is situated in Kyiv (fig. 25) on a promontory, on the right bank of the Dnieper (Шидловський, Прядко 2011). This site was discovered and excavated in 1893 to 1900 by V. Khvoika. He highlighted that lithic remains are anthropogenic product and that these tools were associated with mammoth bones (1913, re-edited in 2008). Some of these tusks presented also anthropogenic modifications (Беляшевский 1900; Волков 1903; Абрамова 1962; Филиппов 1983). The archaeological remains were in clayey sand (Громов 1948). It could have one cultural layer (Пидопличко 1969) or, more likely, two (Хвойка 1913 (2008); Борисковский 1953) (fig. 26).

A $14 \mathrm{C}$ date from mammoth teeth was obtained to $19200 \pm 250 \mathrm{BP}$ (OxA-718) (Abramova, Grigorieva and Zaitsev, 2001; Радієвська, Біленко 2010).

The lithic industry has been studied repeatedly (Вовк 1899а; 18996; Хвойка 1913(2008); Борисковский 1941; 1953; Ефименко 1953; Гладких 1971;1991; Шидловський 2012). The upper layer is the richest with 3000 lithic remains and burned bones. The lower layer furnished 250 lithic remains. Both correspond to characteristics of Upper Palaeolithic industries. P.S. Shydlovskyi and D.V. Stupak revised the material in 2015, based on lithic material kept at the National Museum of Ukrainian History and the Museum of Saint-Germain-en-Laye (France) and on analysis of the work of predecessors. For them, the lithic productions in the two layers are similar to the processes of debiting and shaping. However, the composition of the tools differs. The industry could correspond to later Gravettian (Shydlovskyi, Stupak 2015).

Unfortunately, the distribution of remains is poorly known because there were no recorded during excavations. The fauna of Kyrylivska (MNI: 79; NR: 454) (Хвойка 1913 (2008); Пидопличко 1969) includes mainly woolly mammoth remains (MNI: 70; NR: 440), then woolly rhinoceros, wolf, brown bear, cave lion, cave hyaena, wolverine and the presence of hare was mentionned (fig. 27).

We had access to only a few pieces still kept at the National Museum of Ukrainian History. The taphonomic observations are similar with some bones of this collection, especially concerning bones $n^{\circ} 6$ and $\mathrm{n}^{\circ} 13$.

Fig. 26. Excavations and geology in Kyrylivska (Хвойка 1893; Хвойка 1913), with two cultural layers.

Рис. 26. Розкопки та геологічна ситуація Кирилівської стоянки (Хвойка 1893; Хвойка 1913), з двома культурними шарами.

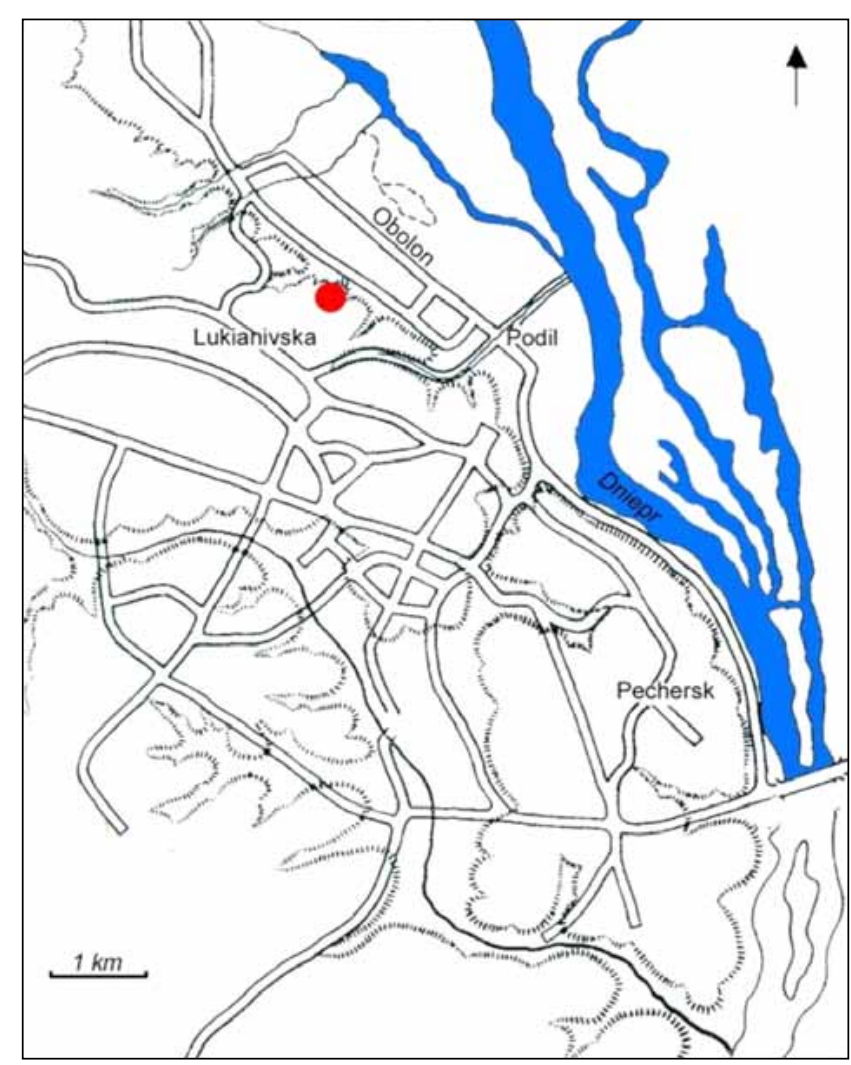

Fig. 25. Localisation of Kyrylivska in Kyiv (after Pidoplichko 1998). Рис. 25. Локалізація Кирилівської стоянки у Києві (за Pidoplichko 1998).

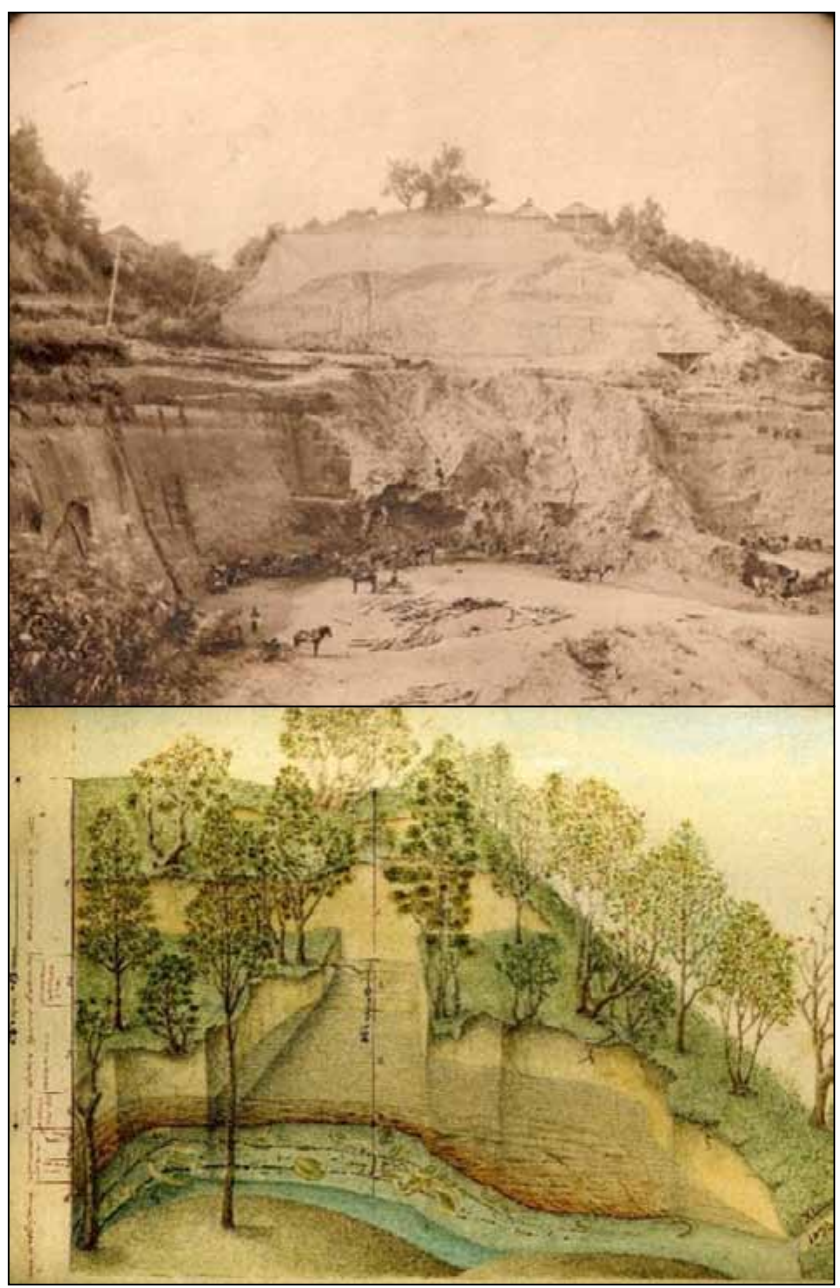




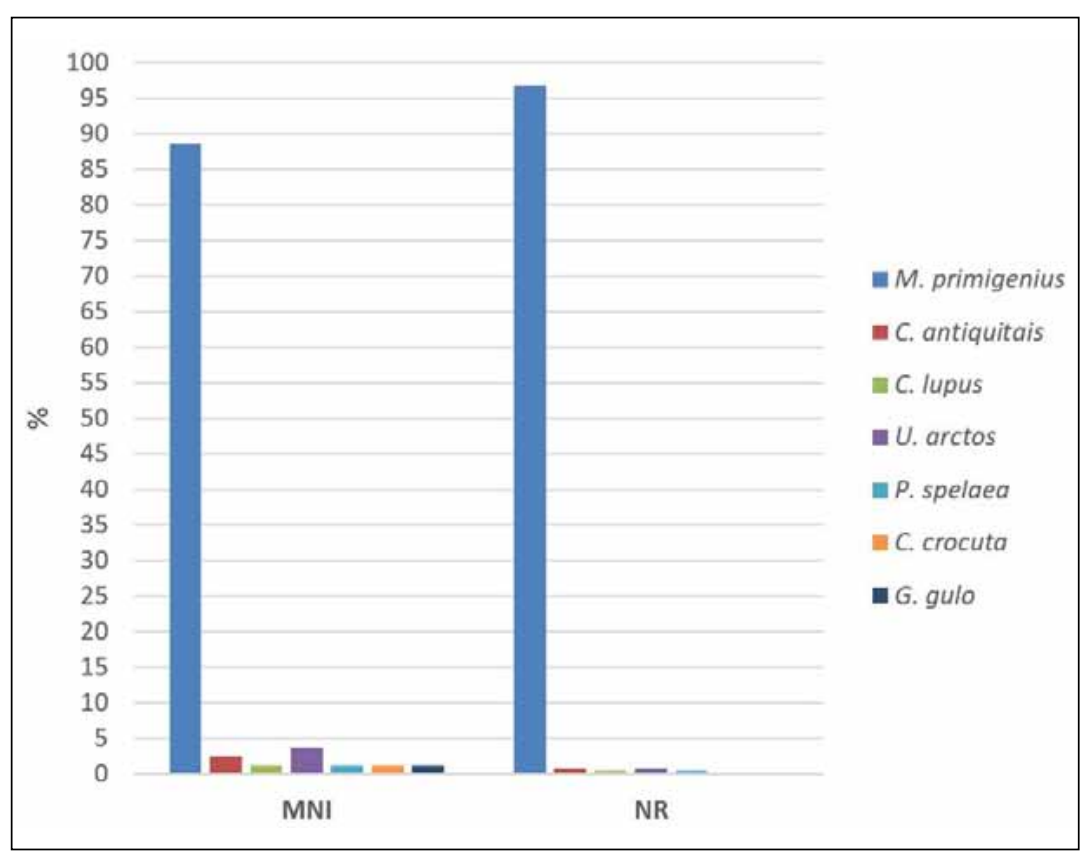

Fig. 27. Faunal spectrum of Kyrylivska (Ukraine) in percentage (after data from Хвойка 1913; Пидопличко 1969).

Рис. 27. Фауністичний спектр Кирилівської стоянки (Україна) у відсотках (за даними Хвойка 1913; Пидопличко 1969).

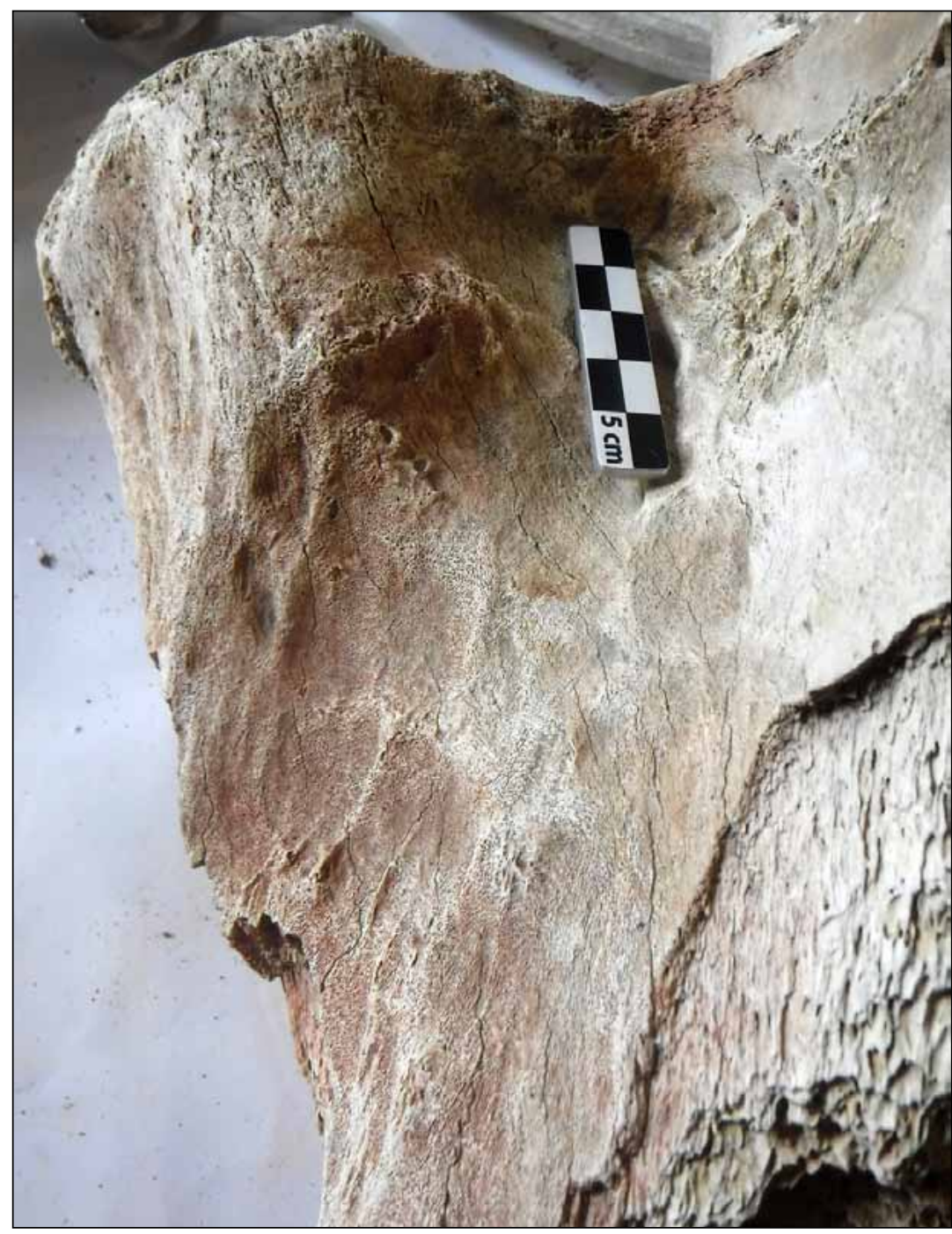

Fig. 28. Bone $\mathrm{n}^{\circ} 13$ (mammoth ulna) with colored deposits.

Рис. 28. Кістка № 13 (ліктьова кістка мамонта) з кольоровим забарвленням.
The colored deposits were not previously described in literature. They are orange-red-brown (fig. 28). They are present on both cortical bone and spongy bone, so they were deposited when the bones were already dry. They could have varied composition (alumino-silicates, ferruginous sandstone, hematite, crinoidal limestone, manganese oxides, iron oxide crystals, ocher sands such as kaolin and bauxite, goethite...) and have different origins (meteorological, biological and pedosedimentary impacts/anthropic implication) (Delamare, 1987; Salomon, 2009; Ardouin, 2012).

Thanks to the study of archival data, it became possible to trace the likely path that these bones took to the National Kyiv-Pechersk Reserve. As a result of the institutional restructuring of the museum network in the late 1920s - during the 1930s, the archaeological collections of Kyiv, including paleontological finds, were concentrated in the KyivPechersk Lavra. In particular, in the early 1930's there was an Archaeological Museum of the Ukrainian Academy of Sciences, in 1934-1935 the All-Ukrainian Historical Museum was moved here (from September 11, 1935 - the Central Historical Museum). As of 1936, the archeological complexes of the Central Historical Museum contained the collections of the former All-Ukrainian Historical Museum named after T. Shevchenko in Kyiv, the Archaeological Museum of Kyiv University, the Archaeological Cabinet of the Kyiv Institute of Public Education, the Archaeological Museum of Higher Women's Courses in Kyiv and the Archaeological Museum of the Ukrainian Academy of Sciences.

Paleolithic materials were presented in the Central Historical Museum by collections of sites: Kyrylivska (excavations by V. Khvoika in 1893-1900), Iskorost (excavations by V. Khvoika in 1911), Mizyn (excavations by Kh. Vovk in 1908, M. Rudynskyi in the 1930s), Zhuravka (excavations by M. Rudynskyi in 1929). In addition, the outskirts of dif- 
ferent villages were presented: Kostyonki (research by O. Kelsiev), Karacharov (research of V. Antonovych, I. Polyakov and V. Dokuchaev in 1878), Vrublevtsi, complexes of materials from locations near the villages Studenytsia (research by V. Antonovych in the 1880s, M. Rudynskyi and M. Musket in 1927-28), Stara Ushytsia (research by M. Rudynskyi and M. Mushket 1927-28) and near Novhorod-Siverskyi (research by M. Rudynskyi in 1925-26).

At the beginning of the Second World War, a part of the collections of the Central Historical Museum were evacuated, but some pieces were left on the territory of the Kyiv-Pechersk Lavra. Later, a part of the remaining collection was transferred to the $\mathrm{Na}$ tional Museum of Prehistory and Early History in Kyiv, and in 1943 - taken to Germany.

After the Second World War, some displaced collections returned in Kyiv. The distribution of these artifacts between museum institutions of the country partly took place on the territory of the Kyiv-Pechersk Reserve. Most of the archaeological collections were transferred to the State Historical Museum, which was restored in 1944. Today, they are part of the Scientific founds of the National Museum of History of Ukraine.
Probably the found collection got to the territory of the National Kyiv-Pechersk Reserve in the postwar period due to the return of materials of Ukrainian museums.

\section{CONCLUSIONS}

The collection contains bones of at least six individuals:

- 1 bear (adult s.l.)

- 2 Cervus sp. (male adult s.l.)

- 3 mammoths (1 female adult s.l.; 1 male adult s.l., 1 young adult).

This collection contains bones from different places of origin. According to the taphonomic observations, it seems belong at least three different assemblages. There is no doubt about the origin from the Illinka Cave, with a very high degree of probability - from the Kyrylivska site, this probability is especially high for bones No. 13 and 6.

The red coloration deposits (ochre?) observed of some bones would require the advice of a specialist.

Most likely, this collection was formed in the Scientific founds of the National Kyiv-Pechersk Reserve because of the return of materials from Ukrainian museums after the Second World War.

\section{ЛІТЕРАТУРА}

Абрамова, 3.А. 1962. Палеолитическое искусство на территории СССР. Свод археологических источников. Археология СССР, А 4-3, 86 с.

Аверьянов, А.О. 1994. Мамонт Кутоманова. Труды Зоологического института РАН, 256, с. 111-135.

Беляшевский, Н. 1900. Бивни мамонта с нарезами из стоянки на Кирилловской ул. в Киеве. Археологическая летопись Южной России, 2, с. 71-71.

Борисковский, П.И. 1941. Кирилловская палеолитическая стоянка. Материалы и исследования по археологии СССР , 2, Москва; Ленинград.

Борисковский, П.И. 1953. Палеолит Украины. Историко-археологические очерки. Материалы и исследования по археологии СССР, 40, Москва; Ленинград: Наука.

Верещагин, Н.К., Тихонов, А.Н. 1986. Исследование бивней мамонтов. Труды Зоологического института АН CCCP, 149, c. 3-14.

Вовк, Хв. 1899а. Передісторичні знахідки на Кирилівській вулиці у Київі. Матеріали до українсько-руської етнології, I, с. 1-32.

Вовк, Хв. 18996. Палеолітичні знахідки на Кирилівській вулиці у Київі. Матеріали до українсько-руської етнології, I, с. 211-219.

Волков, Ф.К. 1903. Искусство Мадленской эпохи в Украине. Археологическая летопись южной России, I, с. $15-26$.

Волосович, К.А. 1909. Раскопки Санга-юряхского мамонта в 1908 году. Известия Императорской Академии Наук, Серия VI. T. III. № 6, с. 437-458.

Волосович, К.А. 1914. Мамонт острова Большого Ляховского (Новосибирские острова). Геологический очерк. Записки Императорского Санкт-Петербургского минералогического общества, II серия. T. L, с. 305-338.

Гарутт, В.Е., Дубинин, В.Б. 1951. О скелете таймырского мамонта. Зоологический журнал, 30 (1), с. 17-23.

Гладких, М.І. 1971. Різні прояви пізньопалеолітичної культури в Середньому Подніпров'ї. Український історичний журнал, 10, с. 99-102.

Гладких, М.І. 1991. Історична інтерпретація пізнього палеоліту (за матеріалами території України). Київ.

Громов, В.И. 1948. Палеонтологическое и археологическое обоснование стратиграфии континентальных отложений четвертичного периода на территории СССР (млекопитающие, палеолит). Труды ГИН АН СССР, 64. Москва: Издательство АН СССР.

Добровольський, А.В. 1950. Печера коло с. Іллінки Одеської області. Археологія, IV, с. 152-155.

Ефименко, П.П. 1953. Первобытное общество. Киев, Издательство АН УССР.

Єфименко, П.П. 1954. Палеолітичні пам'ятки УРСР та сучасний стан їх вивчення. Археологія, IX, с. 168-177. 
Замятнін, С.М. 1950. Про характер культурних залишків у печері коло с. Іллінки, Одеської області. Археологія, IV, c. 143-151.

Підоплічко, І.Г. 1949. Розкопки палеолітичної стоянки Іллінка 1 в 1946 р. Археологічні пам'ятки УРСР, II, с. $323-325$.

Підоплічко, І.Г. 1956. Матеріали до вивчення минулих фаун УРСР. Вun. 2. Київ, Наукова думка.

Пидопличко, И.Г. 1969. Позднепалеолитические жилища из костей мамонта на Украине. Киев, Наукова думка.

Пронин, К.К. 1999. Пещера Ильинка. Свет, 1 (20), с. 30-32.

Радієвська, Т.М., Біленко, М.М. 2010. Перший археологічний досвід В. В. Хвойки. Науково-дослідницька та просвітницька діяльність Вікентія Хвойки. Матеріали науково-практичної конференції Київського обласного археологічного музею. Трипілля. с. 97-104.

Рощін, А.Д. 1939. Нові місця знаходження кісток печерного ведмедя з залишками палеоліту. Bicmi AH УРCP, 9-10, C. 68-71.

Рощін, А.Д. 1941. Викопні ссавці с. Іллінки. Наук. сесія Одеського держ. педінституту. Тези доповідей. с. 79-80.

Сапожніков, І. 2005. Хронологія і періодизація пізнього палеоліту півдня Східної Європи. Матеріали та дослідження з археології Прикарпаття та Волині, 9, с. 14-31.

Сапожников, И.В., Сапожникова, Г.В. 1989. Новое о пещере Ильинка. Четвертичный период, палеонтология и археология. К XXVIII Междунар. геол. конгрессу. с. 179-187.

Филиппов, А.К. 1983. Обивне из Кирилловской позднепалеолитической стоянки. Краткие сообщенияИнститута археологи $А Н C C P, 173$, с. 39-42.

Хвойка, В.В. 2008. Древние обитатели Среднего Приднепровья и их культура в доисторические времена (с комментариями и иллюстрациями). Київ.

Шидловський, П. 2012. Дослідження крем'яного інвентарю Кирилівської стоянки. Вісник Київського начіонального університету імені Тараса Шевченка, 112, с. 53-59.

Шидловський, П.С., Прядко, Д.Ю. 2011. Пізній палеоліт Київського Правобережжя. Археологія і давня історія України, 6, с. 68-85.

Abramova, Z.A., Grigorieva, G.V., Zaitseva, G.I. 2001. The Age of Upper Paleolithic Sites in the Middle Dnieper River Basin of Eastern Europe. Radiocarbon, 43 (2B), p. 1077-1084.

Adams, M. 1808. Some Account of a Journey to the Frozen-Sea, and of the Discovery of the Remains of a Mammoth. The Philadelphia Medical and Physical Journal, Part 1, Vol. 3, p. 120-137.

Agenbroad, L.D. 1994. Taxonomy of North American Mammuthus and biometrics of the Hot Springs mammoths. In: Agenbroad, L.D. and Mead, J.I. (eds.), The Hot Springs Mammoth Site. Rapid City, Fenske Printing, p. 158-207.

Ardouin, A. 2012. Guide pratique pour la description des sols de France, CEN Bourgogne, 24 p.

Averianov, A. 1996. Sexual dimorphism in the mammoth skull, teeth, and long bones. In: Shoshani, J. and Tassy, P. (eds.), The Proboscidea, Oxford, Oxford University Press, p. 280-288.

Baca, M., Stankovic, A., Stefaniak, K., Marciszak, A., Hofreiter, M., Nadachowski, A., Węgleński, P. and Mackiewicz, P. 2012. Genetic analysis of cave bear specimens from Niedźwiedzia Cave, Sudetes, Poland. Palaeontologia Electronica 15(2), $21 \mathrm{~A}, 16 \mathrm{p}$.

Behrensmeyer, A.K. 1978. Taphonomic and ecologic information from bone weathering. Paleobiology 4(2), p. $150-162$.

Bocherens, H., Stiller, M., Hobson, K. A., Martina, P., Rabeder, G., Burns, J.A., Tuetken, T. and Hofreiter, M. 2011. Niche partitioning between two sympatric genetically distinct cave bears (Ursus spelaeus and Ursus ingressus) and brown bear (Ursus arctos) from Austria: Isotopic evidence from fossil bones. Quaternary International 245(2), p. $238-248$.

Coppens, Y. 1958. Le mammouth de l'Atrikanova (Sibérie). Bulletin du Muséum National d'Histoire Naturelle. $2^{\text {nd }}$ Series 3D, Paris, p. 402-406.

Coppens, Y. 1965. Les éléphants du Quaternaire français: dentition, systématique, signification et préhistoire. Actes du XVle Congrès Préhistorique de France, Monaco, 1959, Paris, SPF, p. 403-431.

Delamare, F. 1987. Les pigments à base d'oxydes de fer et leur utilisation en peinture pariétale et murale. PACT 17, p. 331-344.

Denys, C., Patou-Mathis, M. (dir.), 2014. Manuel de Taphonomie, Éditions Errance, Collection Archéologiques, Paris, 284 p.

Driesch, A. von den, 1976. A guide to the Measurement of Animal Bones from Archaeological Sites. Peabody Museum of Archaeology and Ethnology 1, Harvard University, Cambridge, 148 p.

Efremov, I.A. 1940. Taphonomy: a new branch of paleontology. Pan-American Geology, 74, p. 81-93.

Felix, J.P. 1912. Das Mammut von Borna. Leipzig, R. Voigtländers verlag, 52 p.

Garutt, W.E. 1964. Das Mammut Mammuthus primigenius (Blumenbach). Wittemberg Lutherstadt, A. Ziemsen Verlag, 140 p.

Hanks, J. 1972. Growth of the African elephant (Loxodonta africana). African Journal of Ecology, 10, p. $251-272$.

Haynes, G. 1991. Mammoths, Mastodonts and Elephants, Biology, behavior and the Fossil record. Cambridge, Cambridge Press, 413 p.

Kavcik-Graumann, N., Nagel, D., Rabeder, G., Ridush, B. and Withalm, G. 2016. The Bears of Illinka Cave near Odessa (Ukraine). Cranium / Proceedings of the $21^{\text {th }}$ International Cave Bear Symposium, 33 (1), p. 18-25.

Kirillova, I.V., Shidlovskiy, F.K. and Titov, V.V. 2012. Kastykhtakh mammoth from Taimyr (Russia). Quaternary International. Mammoths and their Relatives 2: Biotopes, Evolution and Human Impact V International Conference, Le Puy-en-Velay, 2010. Vol. 276-277, p. 269-277.

Koenigswald, W.V. 1989. Das Mammut von Polchbei Mayen (Eifel). Eiszeitalter und Gegenwart, 39, p. 87-97.

Krumrey, W.A., Buss, I.O. 1968. Age estimation, growth, and relationships between body dimensions of the female elephant. J Mammal, 49(1), p. 22-31. 
Laws, R.M. 1966. Age criteria for the African elephant Loxodonta a. Africana. East African Wildlife Journal, 4, p. 1-37.

Lister, A.M. 1999. Epiphyseal fusion and postcranial age determination in the woolly mammoth, Mammuthus primigenius (Blum.). Deinsea, 6, p. 79-88.

Lister, A. 2009. Late-glacial mammoth skeletons (Mammuthus primigenius) from Condover (Shropshire, UK): anatomy, pathology, taphonomy and chronological significance. Geological Journal, 44, p. 447-479.

Maschenko, E.N., Gablina, S.S., Tesakov, A.S. and Simakova, A.N. 2006. The Sevsk woolly mammoth (Mammuthus primigenius) site in Russia: taphonomic, biological and behavioral interpretations. Quaternary International, 142 (3), p. 147-165.

Nagel, D., Pronin, K., Rabeder, G., Hofreiter, M., Huijer, W., Kavcik, N., Urbanek, C., Withalm, G. and Orlov, N. 2005. Nerubaiskoe, a New Cave Bear Site in the Old Nordmann Territory. Mitteiltungen der Kommission für Quartärforschung, 14, p. 123-134.

Osborn, H.F. 1942. Proboscidea. The American Museum of Natural History, New York.

Petronio, C., di Canzio, E. and di Stefano, G. 2003. Morphological and biometrical differences in the limb bones of Ursus arctos and Ursus spelaeus and phylogenetical considerations on the two species. Palaeontographica Abteilunga, 269, p. 137-152.

Pfizenmayer, E.W. 1926. Mammutleichen und Urwaldmenschen. Leipzig, Brockhaus, 341 p.

Pidoplichko, I.G. 1998. Upper palaeolithic dwellings of mammoth bones in the Ukraine: Kiev-Kirillovskii, Gontsy, Dobranichevka, Mezin and Mezhirich. BAR, International Series 712.

Pontier, G. 1913. Étude sur le Mammouth de l'Aa. Bulletin de la Société préhistorique française, 10, №11, p. 621-646.

Rabeder, G., Hofreiter, M., Nagel, D. and Withalm, G. 2004. New Taxa of Alpine Cave Bears (Ursidae, Carnivora). Cahiers scientifique / Département Rhône - Musée Lyon, Hors série, 2, p. 49-67.

Ridush, B. 2009. "Bear Caves" in Ukraine. Slovensky kras Acta Carsologica slovaca, 47, 1, p. 67-84.

Salomon, H. 2009. Les matières colorantes au début du paléolithique supérieur: sources, transformations et fonctions. Thèse de doctorat, école doctorale Sciences et Environnement, spécialité Préhistoire. Université Bordeaux 1, France, 432 p.

Shoshani, J., Tassy, P. (eds.), 1996. The Proboscidea: evolution and palaeoecology of elephants and their relatives. Oxford, Oxford Science Publications, Oxford University Press, 502 p.

Shydlovskyi, P., Stupak, D. 2015. The research of flint implements on Kyrylivska site. Наукові студіï, 8, c. 21-32.

Siegfried, P. 1959. Das Mammut von Ahlen, Mammonteus primigenius (Blumenb.). Palaeontologische Zeitschrift, 33(3), p. $172-184$.

Toepfer, V. 1957. Die Mammutfunde von Pfännerhall im Geiseltal. Veröffentlichungen des Landes museums für Vorgeschichte, Halle/Saale, 16, $57 \mathrm{p}$.

Vaufrey, R. 1955. Proboscidiens fossiles. Traité de zoologie, T. 17. Grassé. Paris Masson, p. 784-875.

Viola, M. 2014. Caractères ostéologiques du dimorphisme sexuel chez «Mammuthus primigenius». Mémoire de Master 1 Evolution, Patrimoine Naturel et Sociétés Spécialité Quaternaire et Préhistoire, Museum National d'Histoire Naturelle, $24 \mathrm{p}$.

Weinstock, J. 2009. Epiphyseal fusion in brown bears: a population study of grizzlies (Ursus arctos horribilis) from Montana and Wyoming. International Journal of Osteoarchaeology, 19, p. 416-423.

https://www.researchgate.net/journal/International-Journal-of-Osteoarchaeology-1099-1212

Ziegler, R. 1994. Das Mammut (Mammuthus primigenius Blumenbach) von Siegsdorf bei Traunstein (Bayern) und seine Begleitfauna. Münchner Geowissen schaftliche Abhandlungen, 26, p. 49-80.

Ziegler, R. 2001. An extraordinary small mammoth (Mammuthus primigenius) from SW Germany. Geologie und Palaontologie. Stuttgarter Beitrage zur Naturkunde, Series B 300, 41 p.

\section{REFERENCES}

Abramova, Z.A. 1962. Paleoliticheskoe iskusstvo na territorii SSSR. Svod arheologicheskix istochnikov. Arheologiya SSSR, A4-3, 86 s. (in Russian).

Aver yanov, A.O. 1994. Mamont Kutomanova. Trudy`Zoologicheskogo instituta RAN, 256, s. 111-135. (in Russian).

Belyashevskij, N. 1900. Bivni mamonta s narezami iz stoyanki na Kirillovskoj ul. v Kieve. Arxeologicheskaya letopis` Yuzhnoj Rossii, 2, s. 71-71. (in Russian).

Boriskovskij, P.I. 1941. Kirillovskaya paleoliticheskaya stoyanka. Materialy` $i$ issledovaniya po arxeologii SSSR, 2, Moskva; Leningrad. (in Russian).

Boriskovskij, P.I. 1953. Paleolit Ukrainy. Istoriko-arkheologicheskie ocherki. Materialy i issledovaniia po arkheologii SSSR, 40. Moskva; Leningrad: Nauka. (in Russian).

Vereshhagin, N.K., Tihonov, A.N. 1986. Issledovanie bivnej mamontov. Trudy`Zoologicheskogo instituta AN SSSR, 149, s. 3-14. (in Russian).

Vovk, Khv. 1899a. Peredistorychni znakhidky na Kyrylivskii vulytsi u Kyivi. Materialy do ukrainsko-ruskoi etnolohii, I, c. 1-32. (in Ukrainian).

Vovk, Khv. 1899b. Paleolitychni znakhidky na Kyrylivskii vulytsi u Kyivi. Materialy do ukrainsko-ruskoi etnolohii, I, c. 211219. (in Ukrainian).

Volkov, F.K. 1903. Iskusstvo Madlenskoj e poxi v Ukraine. Arheologicheskaya letopis 'yuzhnoj Rossii, I, s. 15-26. (in Russian). Volosovich, K.A. 1909. Raskopki Sanga-yuryaxskogo mamonta v 1908 godu. Izvestiya Imperatorskoj Akademii Nauk, Seriya VI. T. III. № 6, s. 437-458. (in Russian). 
Volosovich, K.A. 1914. Mamont ostrova Bol`shogo Lyaxovskogo (Novosibirskie ostrova). Geologicheskij ocherk. Zapiski Imperatorskogo Sankt-Peterburgskogo mineralogicheskogo obshhestva, II seriya. T. L, s. 305-338. (in Russian).

Garutt, V.E., Dubinin, V.B. 1951. O skelete tajmy’rskogo mamonta. Zoologicheskij zhurnal, 30 (1), s. 17-23. (in Russian).

Hladkykh, M.I. 1971. Rizni proiavy piznopaleolitychnoi kultury v Serednomu Podniprovi. Ukrainskyi istorychnyi zhurnal, 10, s. 99-102. (in Ukrainian).

Hladkykh, M.I. 1991. Istorychna interpretatsiia piznoho paleolitu (za materialamy terytorii Ukrainy). Kyiv. (in Ukrainian).

Gromov, V.I. 1948. Paleontologicheskoe $i$ arheologicheskoe obosnovanie stratigrafii kontinental 'ny 'x otlozhenij chetvertichnogo perioda na territorii SSSR (mlekopitayushhie, paleolit). Trudy` GIN AN SSSR, 64. Moskva: Izdatel 'stvo AN SSSR. (in Russian).

Dobrovolskyi, A.V. 1950. Pechera kolo s. Illinky Odeskoi oblasti. Arkheolohiia, IV, s. 152-155. (in Ukrainian).

Efimenko, P.P. 1953. Pervoby 'tnoe obshhestvo. Kiev, Izdatel’stvo AN USSR. (in Russian).

Yefymenko, P.P. 1954. Paleolitychni pamiatky URSR ta suchasnyi stan yikh vyvchennia. Arkheolohiia, IX, s. 168-177. (in Ukrainian).

Zamiatnin, S.M. 1950. Pro kharakter kulturnykh zalyshkiv u pecheri kolo s. Illinky, Odeskoi oblasti. Arkheolohiia, IV, s. 143-151. (in Ukrainian).

Pidoplichko, I.H. 1949. Rozkopky paleolitychnoi stoianky Illinka 1 v 1946 r. Arkheolohichni pamiatky URSR, II, s. 323-325. (in Ukrainian).

Pidoplichko, I.H. 1956. Materialy do vyvchennia mynulykh faun URSR. Vyp. 2. Kyiv, Naukova dumka. (in Ukrainian).

Pidoplichko, I.G. 1969. Pozdnepaleoliticheskie zhilishha iz kostej mamonta na Ukraine. Kiev, Naukova dumka. (in Russian).

Pronin, K.K. 1999. Peshhera Il’inka. Svet, 1 (20), s. 30-32. (in Russian).

Radiievska, T.M., Bilenko, M.M. 2010. Pershyi arkheolohichnyi dosvid V.V. Khvoiky. Naukovo-doslidnytska ta prosvitnytska diialnist Vikentiia Khvoiky. Materialy naukovo-praktychnoi konferentsii Kyivskoho oblasnoho arkheolohichnoho muzeiu. Trypillia. c. 97-104. (in Ukrainian).

Roshchin, A.D. 1939. Novi mistsia znakhodzhennia kistok pechernoho vedmedia z zalyshkamy paleolitu. Visti AN URSR, 9-10, s. 68-71. (in Ukrainian).

Roshchin, A.D. 1941. Vykopni ssavtsi s. Illinky. Nauk. sesiia Odeskoho derzh. pedinstytutu. Tezy dopovidei. s. 79-80. (in Ukrainian).

Sapozhnikov, I.2005. Khronolohiia i periodyzatsiia piznoho paleolitu pivdnia SkhidnoiYevropy. Materialy ta doslidzhennia z arkheolohii Prykarpattia ta Volyni, 9, s. 14-31. (in Ukrainian).

Sapozhnikov, I.V., Sapozhnikova, G.V. 1989. Novoe o peshhere II'inka. Chetvertichny ’jperiod, paleontologiya i arxeologiya. KXXVIII Mezhdunar. geol. kongressu. s. 179-187. (in Russian).

Filippov, A.K. 1983. O bivne iz Kirillovskoj pozdnepaleoliticheskoj stoyanki. Kratkie soobshheniya Instituta arxeologi AN $S S R, 173$, s. 39-42. (in Russian).

Hvojka, V.V. 2008. Drevnie obitateli Srednego Pridneprov `ya i ix kul ’tura v doistoricheskie vremena (s kommentariyami $i$ illyustracziyami). Kyiv. (in Russian).

Shydlovskyi, P. 2012. Doslidzhennia krem'ianoho inventariu Kyrylivskoi stoianky. Visnyk Kyivskoho natsionalnoho universytetu imeni Tarasa Shevchenka, 112, s. 53-59. (in Ukrainian).

Shydlovskyi, P.S., Priadko, D.Yu. 2011. Piznii paleolit Kyivskoho Pravoberezhzhia. Arkheolohiia i davnia istoriia Ukrainy, 6, s. 68-85. (in Ukrainian).

Abramova, Z.A., Grigorieva, G.V., Zaitseva, G.I. 2001. The Age of Upper Paleolithic Sites in the Middle Dnieper River Basin of Eastern Europe. Radiocarbon, 43 (2B), p. 1077-1084.

Adams, M. 1808. Some Account of a Journey to the Frozen-Sea, and of the Discovery of the Remains of a Mammoth. The Philadelphia Medical and Physical Journal, Part 1, Vol. 3, p. 120-137.

Agenbroad, L.D. 1994. Taxonomy of North American Mammuthus and biometrics of the Hot Springs mammoths. In: Agenbroad, L.D. and Mead, J.I. (eds.), The Hot Springs Mammoth Site. Rapid City, Fenske Printing, p. 158-207.

Ardouin, A. 2012. Guide pratique pour la description des sols de France, CEN Bourgogne, 24 p.

Averianov, A. 1996. Sexual dimorphism in the mammoth skull, teeth, and long bones. In: Shoshani, J. and Tassy, P. (eds.), The Proboscidea, Oxford, Oxford University Press, p. 280-288.

Baca, M., Stankovic, A., Stefaniak, K., Marciszak, A., Hofreiter, M., Nadachowski, A., Węgleński, P. and Mackiewicz, P. 2012. Genetic analysis of cave bear specimens from Niedźwiedzia Cave, Sudetes, Poland. Palaeontologia Electronica 15(2), $21 \mathrm{~A}, 16 \mathrm{p}$.

Behrensmeyer, A.K. 1978. Taphonomic and ecologic information from bone weathering. Paleobiology 4(2), p. $150-162$.

Bocherens, H., Stiller, M., Hobson, K. A., Martina, P., Rabeder, G., Burns, J.A., Tuetken, T. and Hofreiter, M. 2011. Niche partitioning between two sympatric genetically distinct cave bears (Ursus spelaeus and Ursus ingressus) and brown bear (Ursus arctos) from Austria: Isotopic evidence from fossil bones. Quaternary International 245(2), p. $238-248$.

Coppens, Y. 1958. Le mammouth de l'Atrikanova (Sibérie). Bulletin du Muséum National d'Histoire Naturelle. $2^{\text {nd }}$ Series 3D, Paris, p. 402-406.

Coppens, Y. 1965. Les éléphants du Quaternaire français: dentition, systématique, signification et préhistoire. Actes du XVle Congrès Préhistorique de France, Monaco, 1959, Paris, SPF, p. 403-431.

Delamare, F. 1987. Les pigments à base d'oxydes de fer et leur utilisation en peinture pariétale et murale. PACT 17, p. 331-344.

Denys, C., Patou-Mathis, M. (dir.), 2014. Manuel de Taphonomie, Éditions Errance, Collection Archéologiques, Paris, 284 p. 
Driesch, A. von den, 1976. A guide to the Measurement of Animal Bones from Archaeological Sites. Peabody Museum of Archaeology and Ethnology 1, Harvard University, Cambridge, 148 p.

Efremov, I.A. 1940. Taphonomy: a new branch of paleontology. Pan-American Geology, 74, p. 81-93.

Felix, J.P. 1912. Das Mammut von Borna. Leipzig, R. Voigtländers verlag, 52 p.

Garutt, W.E. 1964. Das Mammut Mammuthus primigenius (Blumenbach). Wittemberg Lutherstadt, A. Ziemsen Verlag, $140 \mathrm{p}$.

Hanks, J. 1972. Growth of the African elephant (Loxodonta africana). African Journal of Ecology, 10, p. $251-272$.

Haynes, G. 1991. Mammoths, Mastodonts and Elephants, Biology, behavior and the Fossil record. Cambridge, Cambridge Press, 413 p.

Kavcik-Graumann, N., Nagel, D., Rabeder, G., Ridush, B. and Withalm, G. 2016. The Bears of Illinka Cave near Odessa (Ukraine). Cranium / Proceedings of the $21^{\text {th }}$ International Cave Bear Symposium, 33 (1), p. 18-25.

Kirillova, I.V., Shidlovskiy, F.K. and Titov, V.V. 2012. Kastykhtakh mammoth from Taimyr (Russia). Quaternary International. Mammoths and their Relatives 2: Biotopes, Evolution and Human Impact V International Conference, Le Puy-en-Velay, 2010. Vol. 276-277, p. 269-277.

Koenigswald, W.V. 1989. Das Mammut von Polchbei Mayen (Eifel). Eiszeitalter und Gegenwart, 39, p. 87-97.

Krumrey, W.A., Buss, I.O. 1968. Age estimation, growth, and relationships between body dimensions of the female elephant. J Mammal, 49(1), p. 22-31.

Laws, R.M. 1966. Age criteria for the African elephant Loxodonta a. Africana. East African Wildlife Journal, 4, p. 1-37.

Lister, A.M. 1999. Epiphyseal fusion and postcranial age determination in the woolly mammoth, Mammuthus primigenius (Blum.). Deinsea, 6, p. 79-88.

Lister, A. 2009. Late-glacial mammoth skeletons (Mammuthus primigenius) from Condover (Shropshire, UK): anatomy, pathology, taphonomy and chronological significance. Geological Journal, 44, p. 447-479.

Maschenko, E.N., Gablina, S.S., Tesakov, A.S. and Simakova, A.N. 2006. The Sevsk woolly mammoth (Mammuthus primigenius) site in Russia: taphonomic, biological and behavioral interpretations. Quaternary International, 142 (3), p. 147-165.

Nagel, D., Pronin, K., Rabeder, G., Hofreiter, M., Huijer, W., Kavcik, N., Urbanek, C., Withalm, G. and Orlov, N. 2005. Nerubaiskoe, a New Cave Bear Site in the Old Nordmann Territory. Mitteiltungen der Kommission für Quartärforschung, 14 , p. 123-134.

Osborn, H.F. 1942. Proboscidea. The American Museum of Natural History, New York.

Petronio, C., di Canzio, E. and di Stefano, G. 2003. Morphological and biometrical differences in the limb bones of Ursus arctos and Ursus spelaeus and phylogenetical considerations on the two species. Palaeontographica Abteilunga, 269, p. 137-152.

Pfizenmayer, E.W. 1926. Mammutleichen und Urwaldmenschen. Leipzig, Brockhaus, 341 p.

Pidoplichko, I.G. 1998. Upper palaeolithic dwellings of mammoth bones in the Ukraine: Kiev-Kirillovskii, Gontsy, Dobranichevka, Mezin and Mezhirich. BAR, International Series 712.

Pontier, G. 1913. Étude sur le Mammouth de l'Aa. Bulletin de la Société préhistorique française, 10, N¹1, p. $621-646$.

Rabeder, G., Hofreiter, M., Nagel, D. and Withalm, G. 2004. New Taxa of Alpine Cave Bears (Ursidae, Carnivora). Cahiers scientifique / Département Rhône — Musée Lyon, Hors série, 2, p. 49-67.

Ridush, B. 2009. “Bear Caves” in Ukraine. Slovensky kras Acta Carsologica slovaca, 47, 1, p. 67-84.

Salomon, H. 2009. Les matières colorantes au début du paléolithique supérieur: sources, transformations et fonctions. Thèse de doctorat, école doctorale Sciences et Environnement, spécialité Préhistoire. Université Bordeaux 1, France, 432 p.

Shoshani, J., Tassy, P. (eds.), 1996. The Proboscidea: evolution and palaeoecology of elephants and their relatives. Oxford, Oxford Science Publications, Oxford University Press, 502 p.

Shydlovskyi, P., Stupak, D. 2015. The research of flint implements on Kyrylivska site. Наукові студіï, 8, c. 21-32.

Siegfried, P. 1959. Das Mammut von Ahlen, Mammonteus primigenius (Blumenb.). Palaeontologische Zeitschrift, 33(3), p. 172-184.

Toepfer, V. 1957. Die Mammutfunde von Pfännerhall im Geiseltal. Veröffentlichungen des Landes museums für Vorgeschichte, Halle/Saale, 16, $57 \mathrm{p}$.

Vaufrey, R. 1955. Proboscidiens fossiles. Traité de zoologie, T. 17. Grassé. Paris Masson, p. 784-875.

Viola, M. 2014. Caractères ostéologiques du dimorphisme sexuel chez «Mammuthus primigenius». Mémoire de Master 1 Evolution, Patrimoine Naturel et Sociétés Spécialité Quaternaire et Préhistoire, Museum National d'Histoire Naturelle, 24 p.

Weinstock, J. 2009. Epiphyseal fusion in brown bears: a population study of grizzlies (Ursus arctos horribilis) from Montana and Wyoming. International Journal of Osteoarchaeology, 19, p. 416-423.

https://www.researchgate.net/journal/International-Journal-of-Osteoarchaeology-1099-1212

Ziegler, R. 1994. Das Mammut (Mammuthus primigenius Blumenbach) von Siegsdorf bei Traunstein (Bayern) und seine Begleitfauna. Münchner Geowissen schaftliche Abhandlungen, 26, p. 49-80.

Ziegler, R. 2001. An extraordinary small mammoth (Mammuthus primigenius) from SW Germany. Geologie und Palaontologie. Stuttgarter Beitrage zur Naturkunde, Series B 300, 41 p. 
Демей Лєтісія', Тараненко Сергій Пантелійович²,

$1 \mathrm{PhD}$, науковий співробітник, Національний природничий музей адреса: вул. Рене Панхард, 1, Париж, 75013, Франція

ORCID: 0000-0003-4930-7030

e-mail: laetitia.demay@mnhn.fr

2 к.і.н., завідувач науково-дослідного сектору археології Національного Заповідника «Києво-Печерська лавра» адреса: вул. Лаврська, 9, Київ, 01015, Україна

ORCID: $0000-0003-0590-9726$

e-mail: taransun@ukr.net

3 к.і.н., провідний науковий співробітник науково-дослідного відділу історії та археології, Національний заповідник «Києво-Печерська лавра» адреса: вул. Лаврська, 9, Київ, 01015, Україна

ORCID: 0000-0003-0713-3087

e-mail: pudovkina@ukr.net

4 к.і.н., науковий співробітник, Інститут археології НАН України

адреса: просп. Героїв Сталінграда 12, Київ, 04210, Україна

ORCID: 0000-0002-0809-2179

e-mail: stupak17@ukr.net

\section{НЕЗВИЧАЙНА ФАУНІСТИЧНА КОЛЕКЦІЯ 3 НАУКОВИХ ФОНДІВ НАЦІОНАЛЬНОГО КИЄВО-ПЕЧЕРСЬКОГО ЗАПОВІДНИКА}

у 2017 р. у Наукових фондах Національного Києво-Печерського заповідника випадково виявлено фауністичну колекцію з 17 кісток. Основою її були кістки мамонта. Звісно, одразу постало питання про походження цієї збірки. Після первинного огляду цього матеріалу стало зрозумілим, що кістки походять з різних місцезнаходжень. У вересні 2017 року колекцію проаналізувала Летісія Демей (таблиця 1).

Ці кістки належать, як мінімум шести особинам - 1 Ursus sp.; 2 - Cervus sp.; 3 - Mammuthus primigenius. 3riдно з тафономічними спостереженнями, здається, що вони належать принаймні до трьох різних сукупностей.

Немає жодних сумнівів щодо походження кістки ведмедя з печери Іллінка, про що свідчить шифр, якій на ній зберігся. 3 дуже високим ступенем ймовірності походження деяких кісток з Кирилівської стоянки. Ця ймовірність особливо висока для кісток № 13 та 6.

Червоні забарвлення (вохра?), які спостерігаються на деяких кістках, потребують консультації фахівця.

Завдяки вивченню архівних даних стало можливим простежити ймовірний шлях, яким ці кістки потрапили до Національного Києво-Печерського заповідника. Після Другої світової війни одним із центрів повернення музейних експонатів, переміщених під час війни, був Київ. Розподілення цих колекцій між музейними установами країни частково відбувалося на території Києво-Печерського заповідника. Більшість археологічних колекцій було передано до Державного історичного музею, який був відновлений у 1944 р. Сьогодні вони є частиною Наукових фондів Національного музею історії України.

Имовірно, знайдена колекція сформувалась на території Національного Києво-Печерського заповідника і залишилась у Наукових фондах у повоєнний період, у процесі повернення матеріалів українських музеїв.

Ключові слова: Національний Києво-Печерський заповідник, печера Іллінка, Кирилівська стоянка, повернені колекції. 